University of Nebraska - Lincoln

DigitalCommons@University of Nebraska - Lincoln

Occurrence of arsenite in surface and groundwater associated with a perennial stream located in Western Nebraska, USA

Arindam Malakar

Rajesh Singh

Jeffrey Westrop

Karrie A. Weber

Christopher N. Elofson

See next page for additional authors

Follow this and additional works at: https://digitalcommons.unl.edu/watercenterpubs

Part of the Environmental Indicators and Impact Assessment Commons, Fresh Water Studies Commons, Hydraulic Engineering Commons, Hydrology Commons, Sustainability Commons, and the Water Resource Management Commons

This Article is brought to you for free and open access by the Water Center, The at DigitalCommons@University of Nebraska - Lincoln. It has been accepted for inclusion in Faculty Publications from The Water Center by an authorized administrator of DigitalCommons@University of Nebraska - Lincoln. 
Authors

Arindam Malakar, Rajesh Singh, Jeffrey Westrop, Karrie A. Weber, Christopher N. Elofson, Manish Kumar, and Daniel D. Snow 


\title{
Occurrence of arsenite in surface and groundwater associated with a perennial stream located in Western Nebraska, USA
}

\author{
Arindam Malakar, ${ }^{1}$ Rajesh Singh, ${ }^{2}$ Jeffrey Westrop, ${ }^{3}$ \\ Karrie A. Weber, ${ }^{3,4}$ Christopher N. Elofson, ${ }^{3}$ \\ Manish Kumar, ${ }^{5}$ Daniel D. Snow ${ }^{6}$
}

1 Nebraska Water Center, part of the Robert B. Daugherty Water for Food Global Institute, 109 Water Sciences Laboratory, University of NebraskaLincoln, Lincoln, NE 68583-0844, USA

2 Environmental Hydrology Division, National Institute of Hydrology, Roorkee, 247667, Uttarakhand, India

3 School of Biological Sciences and Robert B. Daugherty Water for Food Institute, University of Nebraska-Lincoln, 232 Manter Hall, Lincoln, NE 68588-0118, USA

4 Department of Earth and Atmospheric Sciences and Robert B. Daugherty Water for Food Global Institute, University of Nebraska-Lincoln, 316 Bessey Hall, Lincoln, NE 68588-0340, USA

5 Discipline of Earth Sciences, Indian Institute of Technology Gandhinagar, 382355 Gujarat, India

6 School of Natural Resources and Nebraska Water Center, Part of the Robert B. Daugherty Water for Food Global Institute, 202 Water Sciences Laboratory, University of Nebraska-Lincoln, Lincoln, NE 68583-0844, USA

Corresponding author - D. Snow, email dsnow1@unl.edu

Published in Journal of Hazardous Materials 416 (2021) 126170

doi:10.1016/j.jhazmat.2021.126170

Copyright (c) 2021 Elsevier B.V. Used by permission.

Submitted 11 November 2020; revised 13 April 2021; accepted 18 May 2021; published

21 May 2021. 


\begin{abstract}
Dissolved arsenic typically results from chemical weathering of arsenic rich sediments and is most often found in oxidized forms in surface water. The mobility of arsenic is controlled by its valence state and also by its association with iron oxides minerals, the forms of which are both influenced by abiotic and biotic processes in aqueous environment. In this study, speciation methods were used to measure and confirm the presence of reduced arsenic species in the surface water of Frenchman creek, a gaining stream that crosses the Colorado- Nebraska border. Selective extraction analysis of aquifer and stream bed sediments shows that the bulk of the arsenic occurs with labile iron-rich oxy(hydroxide) minerals. Total dissolved arsenic in surface and groundwater ranged from $\sim 3-18 \mu \mathrm{g} \mathrm{L}-1$, and reduced arsenic species comprise about $41 \%$ of the total dissolved arsenic (16.0 $\left.\mu \mathrm{g} \mathrm{L}^{-1}\right)$ in Frenchman creek. Leachable arsenic in the aquifer sediment samples ranged up to $1553 \mu \mathrm{g} \mathrm{kg}^{-1}$, while samples from Frenchman creek bed sediments contained $4218 \mu \mathrm{g} \mathrm{kg}^{-1}$. Dynamic surface and groundwater interaction sustains arsenite in iron-rich surface headwaters, and the implied toxicity of reduced arsenic in this hydrogeological setting, which can be important in surface water environments around the globe.
\end{abstract}

Keywords: arsenic, surface-groundwater interaction, reducing environment, headwaters, sediment, speciation

\title{
1. Introduction
}

Arsenic can occur both in primary and authigenic minerals and is found often in coprecipitated forms in soils and sediments. Abiotic and biologically-catalyzed weathering reactions result in arsenic mobilization leading to elevated concentrations in ground and surface water sources throughout the globe (Missimer et al., 2018). The release of previously sequestered arsenic from soils and sediments is well-recognized to result in geogenic contamination of drinking water and presents significant health risks to human and other living organisms (Malakar et al., 2016; Singh and Stern, 2017; Podgorski and Berg, 2020). The increasing incidence of elevated arsenic from across the globe underlines our concerns for health hazard through possible human exposure via drinking water (Shankar et al., 2014). As per the recommendations of the World Health Organization (WHO), an arsenic concentration above $10 \mu \mathrm{g} \mathrm{L}^{-1}$ induces toxicity, causing serious health conditions including cancer in skin, lungs, bladder and kidney. Inorganic arsenic at circumneutral $\mathrm{pH}$ occurs primarily as either arsenite, As (III) $\left(\mathrm{H}_{3} \mathrm{AsO}_{3}\right)$ or arsenate, $\mathrm{As}(\mathrm{V})\left(\mathrm{H}_{2} \mathrm{AsO}_{4}{ }^{-}\right.$and $\left.\mathrm{HAsO}_{4}{ }^{2-}\right)$. The 
relative toxicity of arsenic to humans depends on the valence state, where the reduced form ( $\mathrm{As}(\mathrm{III})$ ) is more toxic to humans than the oxidized form $(\mathrm{As}(\mathrm{V}))$ due to higher retention time in the body (Malakar et al., 2016).

The prevalence of reduced $\mathrm{As}(\mathrm{III})$ or oxidized $\mathrm{As}(\mathrm{V})$ in water is generally dependent on the physicochemical conditions that are present in soils, sediments, and aqueous environment (Sorg et al., 2014). Under anoxic conditions prevalent in groundwater, As(III) is dominant whereas $\mathrm{As}(\mathrm{V})$ is more dominant in aerobic environments more predominant in surface water (Stubbe et al., 2011). Most naturally occurring arsenic in soils and aquifer sediments is associated with metal oxides/hydroxides (specifically of iron), either adsorbed to the mineral surfaces or incorporated in the crystal structure (Strawn, 2018). Arsenic adsorption to iron oxide minerals is dependent on the oxidation state of arsenic and $\mathrm{pH}$ whereby it can form strong inner and/or outer sphere complexes based on the charge of the arsenic species (Dixit and Hering, 2003; Fendorf et al., 2010; Fan et al., 2014; OnaNguema et al., 2005; Ona-Nguema et al., 2009; Wang et al., 2014; Wu et al., 2018). In addition to direct redox effects, the mobility of arsenic can be attributed to changes in its association with iron oxides minerals which in turn are influenced by both abiotic and biotic factors (Dixit and Hering, 2003; Mackay et al., 2014; Mladenov et al., 2014; Neumann et al., 2014; Neil and Jun, 2016; Nickson et al., 1998, 2000; Sathe et al., 2018). Microorganisms are capable of directly altering arsenic mobility through the change in arsenic redox state and may also bring about reductive dissolution of iron (oxyhydr)oxides/ oxides minerals.

Reductive dissolution of iron oxide minerals can release arsenic into the surrounding soil pore water (Ding et al., 2018; Malakar et al., 2020; Melton et al., 2014; Miot and Etique, 2016; Mladenov et al., 2010, 2015; Nghiem et al., 2020; von der Heyden and Roychoudhury, 2015; Whaley-Martin et al., 2016; Wu et al., 2018). Under reducing conditions iron can be utilized as a terminal electron acceptor also favoring reduction of $\mathrm{As}(\mathrm{V})$ to $\mathrm{As}$ (III) (Fan et al., 2014; Fendorf et al., 2010; Herbel and Fendorf, 2006; Kocar and Fendorf, 2009; Rawson et al., 2016). The production of dissolved As(III) can influence mobility, as arsenite is known to be more mobile compared to arsenate (Malakar et al., 2016). However, under oxic conditions, both arsenic and iron can be oxidized 
chemically and biologically (Straub et al., 2001; Ilbert and Bonnefoy, 2013; Bissen and Frimmel, 2003; Tallman and Shaikh, 1980). a These results in iron oxide precipitation and subsequent adsorption of arsenic (charged arsenates) to the iron-oxyhydroxide (Fe- $\mathrm{OOH})$ mineral surfaces and removal from pore water. These interrelated processes are all important in considering arsenic mobility, occurrence, and potential for human exposure through drinking water.

Groundwater in south-western Nebraska is generally low in dissolved organic carbon, and tends to be dominated by high dissolved oxygen and bicarbonate, which differs markedly from the reducing, carbonate-poor systems widely studied in the context of arsenic mobilization (Aparicio et al., 2000; Rowland et al., 2006; Smedley et al., 2003). Elevated arsenic concentrations have been previously reported in Nebraska public supply wells and sources are generally considered to be geogenic (Gosselin et al., 2006). While the occurrence of reduced arsenic in these public water systems has been previously reported, accumulation, mobilization and persistence of As(III) in surface water at a stream headwater fed by local groundwater has not. In the present study, we evaluate the source(s) and forms of arsenic in the surface and groundwater at Wauneta, NE in the panhandle of western Nebraska and link it to the sediments in the region. Reduced arsenic (As(III)) was found to be prevalent in the surface water of the creek (stream) at the study site. Creek bed sediments presented unique redox hot spots, which controlled arsenic mobility, and stabilized reduced arsenic in the surface water.

\section{Material and methods}

\subsection{Study area}

Frenchman creek is a first-order groundwater-fed perennial stream with an average discharge around 20 cfs waterway. The creek is 267 $\mathrm{km}$ in length that crosses the Colorado-Nebraska border. (USGS 06834000 Frenchman creek at Palisade, Nebraska; Waterdata.gov). Groundwater levels in the upper reaches of the watershed have experienced significant declines leading to westward migration of baseflow due to an increasing density of irrigation wells installed between 1950 
and 2020 (Traylor and Zlotnik, 2016). Perennial baseflow now exists approximately $20 \mathrm{~km}$ east of the Colorado-Nebraska border (Traylor and Zlotnik, 2016). Downstream flow is maintained by growing season releases from Enders Reservoir located approximately $10 \mathrm{~km}$ upstream from Wauneta, NE (Fig. 1a).

Previous investigations have described the hydrogeology of the upper Frenchman creek valley and strata includes Quaternary and Tertiary deposits (Cardwell and Jenkins, 1963). Regionally, higher arsenic concentrations are generally associated with water bearing units in the older Tertiary Ogallala group aquifer consisting of sand, siltstone with channel fill gravels (Gosselin et al., 2006). The sediments sampled for this study are similar material, and based on detailed textural descriptions the subsurface lithology of the area can be divided into five zones (Fig. 1b). The unsaturated zone (Zone Q) extending to the water table (blue line in Fig. $1 \mathrm{~b}$ ) consists of a mixture of Quaternary alluvium (stream gravel, sand, silt, and clay), dune sands (fine to coarse sand), and the Pleistocene Sanborn Formation silt with large amounts of sand and loess. At and below the water table, Zone A is composed of clean sands/gravels separated by silty/mud-rich layers with some thin limestone beds. The sand bodies are not laterally continuous and may be part of the Ogallala Formation. Depth from $\sim 873 \mathrm{~m}$ to $\sim 865 \mathrm{~m}$ is mostly composed of calcareous sands/gravels, mixed with clays and silts and also contains thin, hard limestone beds (caliche) (Zone B). This zone appears laterally continuous and is also likely to be Ogallala formation. The next layer beneath $865 \mathrm{~m}$ consists of clay that overlies mixed gravel/clay (Zone C). Lastly, the deepest layer sampled is mainly composed of organic-rich marine black shale with thin beds of bentonite, gypsum, and sand, and is part of the Cretaceous Pierre shale formation (Zone D). The configuration of the water table suggests that Frenchman's creek is a losing stream along this stretch.

\subsection{Surface water, groundwater, and sediment collection}

Surface and groundwater samples were collected in 2016 both from Frenchman creek and from public drinking water supply wells (PWS) located throughout Wauneta, NE $\left(40^{\circ} 24^{\prime} 59^{\prime \prime} \mathrm{N}\right.$ and $\left.101^{\circ} 22^{\prime} 21^{\prime \prime} \mathrm{W}\right)$ (Fig. 1a). The sampling and coring were undertaken to characterize 
a)

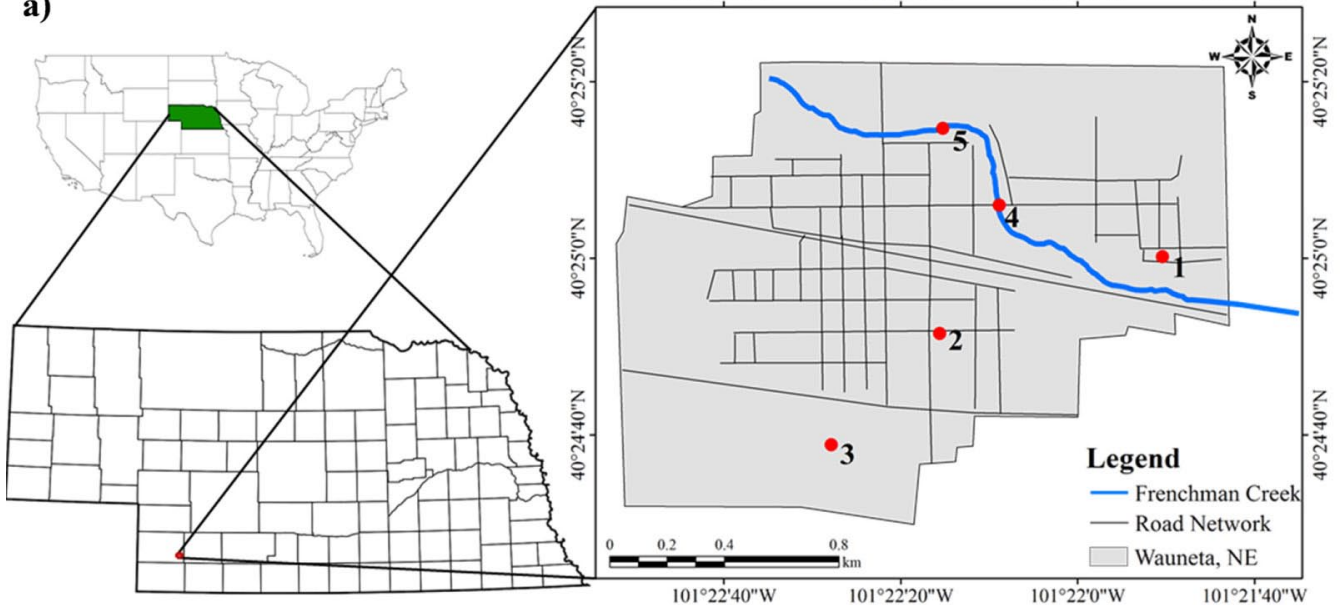

b)

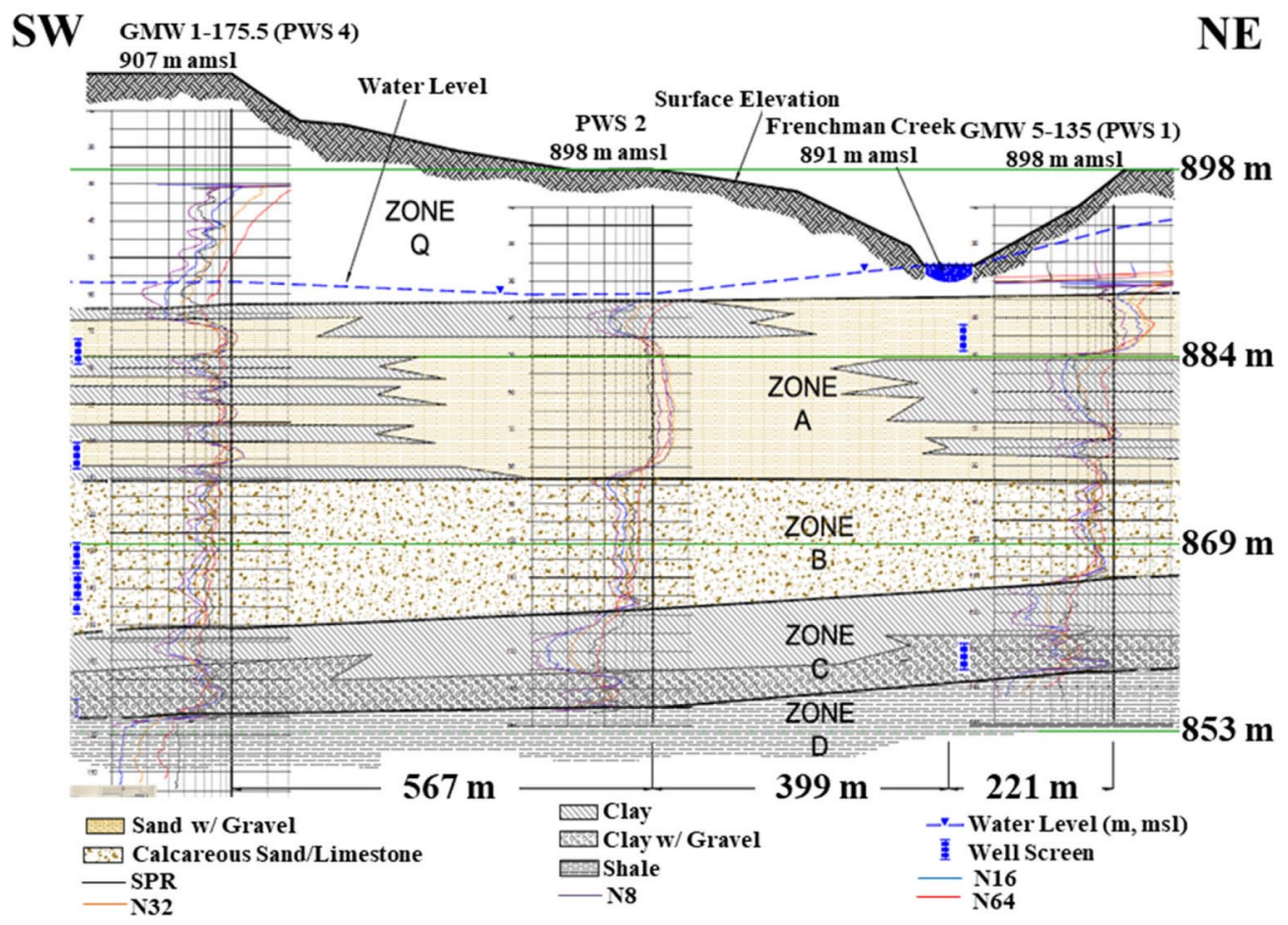

Fig. 1. (a) Locations of the supply wells and multilevel monitoring wells relative to Frenchman creek in Wauneta, Nebraska, USA. Number marked in the map designates as follows: 1 indicates locations of PWS-1, GMW- 5-50 \& GMW-6-135; 2 locates PWS-2; 3 - PWS- 4, GMW-1-175, GMW-2-147, GMW3-105 \& GMW-4-77; 4 indicates Frenchman creek surface water samples; and 5 shows Frenchman creek core location (b) Subsurface geologic cross section for Wauneta, NE based on Gamma Ray and Resistivity logs and checked against well cuttings and cores (Geospec Drilling, 2016). 
local hydrogeology and determine whether well reconstruction could be used to help reduce increasing arsenic concentrations in selected municipal wells. Subsurface sediment cores were collected from four locations, three were near the PWS (PWS1, PWS2, and PWS4) and one in the Frenchman creek sediment bed. Locations of the PWS wells and multilevel groundwater monitoring wells (GMWs) relative to Frenchman creek in Wauneta, NE are provided in Fig. 1. GMW-550 and GMW- 6-135 are located in the north east side of the creek near the vicinity of PWS1. GMW-5-50 and GMW-6-135 represented Zone $\mathrm{A}$ and Zone $\mathrm{C}$ respectively. PWS2, is located at the center of the city. GMW-1-175, GMW-2-147, GMW-3-105, and GMW-4-77 are located near PWS 4 and represented Zone C, B, A, A, respectively. Additional groundwater samples were collected from monitoring wells near Wauneta High School (WHS), \#FP 1, 2, and 3, and Recovery wells (RDW) 1 and 2 previously installed to remediate petroleum contamination.

Groundwater samples for arsenic species were collected using a peristaltic pump and immediately filtered $(0.22 \mu \mathrm{m}$, Whatman GD/XP, GE USA) into brown polyethylene bottles (pre-treated to remove contamination) and preserved by the addition of $0.5 \mathrm{ml}$ of $0.1 \mathrm{M}$ ethylenediamine tetracetic acid (EDTA, Sigma-Aldrich, St. Louis, MO, USA) and hydrochloric acid $\left(\mathrm{HCl}\right.$ TraceMetal ${ }^{\mathrm{TM}}$ Grade, Fisher Chemical ${ }^{\mathrm{TM}}$, USA). This preservation method has previously been reported to be suitable for stabilizing concentrations of $A s(I I I)$ and $A s(V)$, and can also be used for dissolved arsenic (Samanta and Clifford, 2005; Wu and Pichler, 2016). For dissolved arsenic, the filtered samples were preserved by acidification $(\mathrm{pH}<2)$ with conc. nitric acid (trace certified 67\% 16 M), Merck, USA). Samples collected for total arsenic were unfiltered and preserved with nitric acid $(\mathrm{pH}<2)$. Multiple unfiltered and filtered $(0.22 \mu \mathrm{m}$, Whatman GD/XP, GE USA) surface water samples for total arsenic, dissolved arsenic and arsenic speciation were collected by hand in separate bottles from the headwater of Frenchman creek (FC-HW), $5 \mathrm{~m}$ away from the headwater (FC-HW-5 m), Ender's Reservoir (ER), Ender's Reservoir dam (ERD), and Frenchman creek water near PWS-1 (FC-PWS1), and preserved similar to groundwater samples. Additional water samples were later collected from monitoring wells for major ion analysis and dissolved organic carbon to help with interpretation of arsenic results. 
Saturated zone sediment cores were collected from four locations around Wauneta: PWS 1, PWS 2, PWS 4, and Frenchman creek (Fig. 1a). Intact cores $(0.045 \mathrm{~m}$ by $1.52 \mathrm{~m})$ were collected by a direct-push method (Geoprobe Systems, USA) with sediment contained in polyacetate liners supplied by the company. At PWS 4, a layer at $12.9 \mathrm{~m}$ was impenetrable by the direct-push unit and that coring required the use of mud-rotary drilling with water or bentonite drilling mud. Once the impenetrable layer at $12.9 \mathrm{~m}$ was penetrated the Geoprobe was re-positioned over the borehole to resume drilling. As such sediment samples were not collected from $12.9 \mathrm{~m}$ to $15.2 \mathrm{~m}$ at this location. Upon collection, caps were placed on the sediment cores and sealed with paraffin wax. The cores were then placed in argon-flushed polyvinyl chloride (PVC) tubes, shipped on ice until transfer to a walk-in cooler $\left(-4^{\circ} \mathrm{C}\right)$ to help maintain subsurface conditions. Core sediments were later processed in an anaerobic glove bag $\left(5 \% \mathrm{H}_{2}, 19 \% \mathrm{CO}_{2^{\prime}}\right.$, balance $\mathrm{N}_{2}$ ) to assess the concentrations and valance state of iron and arsenic in the collected sediments.

\subsection{Geochemical analyses}

Dissolved arsenic was measured using a hexapole inductively coupled plasma mass spectrometry (ICP-MS) (Platform XS, GV Instruments, Manchester, UK), calibrated over the range of $0.1-100 \mu \mathrm{g}$ $\mathrm{L}^{-1}$ using standards prepared in 1\% nitric acid (Optima Trace Metal Grade, Fisher Scientific ${ }^{\mathrm{TM}}$, USA) from a stock standard of $1000 \mathrm{mg} \mathrm{L}^{-1}$ (SPEX CertiPrep) obtained from Fisher Scientific (St. Louis, MO, USA). Arsenic species were separated and measured using ion chromatography (IC) with multi-mode ion exchange chromatographic column (ASK-1, Micromass, Manchester, UK) directly coupled to the ICPMS (Xie et al., 2002). A mobile phase of $10 \mathrm{mM} \mathrm{NH}_{4} \mathrm{NO}_{3}$ and $0.05 \%$ $\mathrm{HNO}_{3}$ supplied by an isocratic HPLC pump (SSI Series I, State College, USA) provided separation of As(III) and As(V). Calibration standards of $\mathrm{As}(\mathrm{III})$ and $\mathrm{As}(\mathrm{V})$ were prepared from sodium arsenite and sodium arsenate, respectively (Sigma Aldrich, St. Louis, MO USA). The response and calibration for $\mathrm{As}(\mathrm{III})$ and $\mathrm{As}(\mathrm{V})$ species were checked under the same instrumental conditions as the samples using certified standards (SPEX CertiPrep) obtained from Fisher Scientific (St. Louis, MO, USA). 
Subsequently-collected water samples were analyzed for $\mathrm{pH}$ (SympHony multimeter with multiprobe, VWR, USA), major cations $\left(\mathrm{Ca}^{2+}\right.$, $\mathrm{Mg}^{2+}$ and $\left.\mathrm{Na}^{+}\right)$and major anions $\left(\mathrm{HCO}^{3-}, \mathrm{Cl}^{-}, \mathrm{NO}^{3-}, \mathrm{SO}_{4}{ }^{2-}\right.$, and $\left.\mathrm{F}^{-}\right)$following US EPA methods at the Nebraska State Department of Health Environmental Laboratory, Lincoln, Nebraska, USA. Dissolved organic carbon (DOC) was measured by the hot persulfate oxidation method using an OI Model 1010 Carbon Analyzer (OI Analytical, College Station, TX, USA). The core sediments were sampled and characterize for $\mathrm{pH}$ (SympHony multimeter with multiprobe, VWR, USA), oxidation-reduction potential (ORP) (SympHony multimeter with multiprobe, VWR, USA), iron, and easily mobilized arsenic in an anaerobic chamber using a sterile technique. Quality controls for dissolved and extracted arsenic, arsenic species, and dissolved organic carbon included analysis of method blanks, fortified method blanks, and laboratory duplicates at a frequency of not less than $5 \%$. Blank concentrations were below detection, laboratory duplicates results fell within $10 \%$ of each other and results for diluted certified reference standards by IC-ICPMS showed good agreement $( \pm 10 \%)$ with expected values.

\subsection{Sequential extraction}

Extraction of arsenic forms associated with different phases in subsurface and creek bottom sediments $(n=3)$ was done by the modified five step sequential extraction procedure (SEP) (Hamon et al., 2004; Haque et al., 2008; Wenzel et al., 2001). Fig. S1 provides the detailed SEP scheme. Actual toxicity of many contaminants like arsenic, which occur in soils and sediments have been found to be dependent on the relative ease with which the fractions leach out of solid phase rather than their total concentrations (in soil, sediments and minerals) (Wenzel et al., 2001). The method was validated by processing a standard reference material (SRM) $2710 a$, which is a soil from Montana, USA with a particle size $<74 \mu \mathrm{m}$.

The partition coefficient was calculated using the ratio of the quantity in the soil/sediment $\left(C_{T}\right)$ phase to the quantity that has been leached out $\left(C_{L}\right)$ Krupka et al., 1999, using the formula (1):

$$
K_{d}=\frac{C_{T}}{C_{L}}
$$


Two different partition coefficients were calculated in our studies, $\mathrm{K}_{\mathrm{d} 1}$ (where the sum of fractions I and II of arsenic fractionation was taken as $C_{\mathrm{L}}$ ) and $\mathrm{K}_{\mathrm{d} 2}$ (where the groundwater arsenic level of the corresponding sites was considered $\mathrm{C}_{\mathrm{L}}$ ). Comparative values of $\mathrm{K}_{\mathrm{d} 1}$ and $\mathrm{K}_{\mathrm{d} 2}$ were evaluated and then assessed against other variables by utilizing correlation coefficient to ascertain the trend. Sediments from Frenchman creek were from creek bed (FC-A) and $3 \mathrm{~m}$ depth (FC-B), PWS1 sample at $5.8 \mathrm{~m}$ (PWS-1A) and $34.4 \mathrm{~m}$ (PWS-1B), and at PWS 4 sample at $18.8 \mathrm{~m}$ (PWS-4A) and $34.5 \mathrm{~m}$ (PWS-4B). FC-A $0.03 \mathrm{~m}$ (creek bed sediment sample, to understand influence of creek bed sediments in surface head water arsenic species concentration) and FC-B at 3.3 $\mathrm{m}$ (deeper sediment sample for understanding influence of groundwater-surface water interaction on the sediment cores of the creek), PWS1-A at $5.8 \mathrm{~m}$ just above the water level (Fig. 1b) and PWS-1B at $34.4 \mathrm{~m}$ for deeper sediment and PWS4-A at $18.9 \mathrm{~m}$ just above the water level (Fig. 1b) and PWS-4B at $34.7 \mathrm{~m}$ depth for deeper sediments, as sampled in PWS1.

\subsection{Arsenic desorption rates}

Desorption rates of arsenic from core sediments $(n=3)$ were determined by equilibrating with a solution that mimicked the groundwater chemistry, artificial groundwater (AGW) detail of composition can be found in Supporting Information (SI) Table S1, of the study area at a solid to solution ratio (SSR) of 1:10 for $24 \mathrm{~h}$ in anoxic condition. The aliquot was then centrifuged and filtered through 0.45 $\mu \mathrm{m}$ PVDF syringe filter. Half of the liquid was acidified and stored for arsenic analysis by ICP-MS and the remaining half was passed through a Supel-Select SAX (Sigma, USA) filter to remove As(V) from the liquid. Further, the labile arsenic in the sediments was desorbed quantitatively, with minimal dissolution of crystalline matrix, by equilibrating with the CARB solution (14.4 $\mathrm{mM} \mathrm{NaHCO}_{3}+$ $2.8 \mathrm{mM} \mathrm{Na}_{2} \mathrm{CO}_{3}$ ) at 1:10 SSR for $384 \mathrm{~h}$ (Hafeznezami et al., 2016; Kohler et al., 2004). 


\subsection{Sequential extraction of iron}

Functional forms of iron in selected core samples were determined by sequential extraction. The amorphous Fe-oxyhydroxides $\left(\mathrm{Fe}_{\text {Amorphous }}\right)$ were extracted by equilibrating three sediments replicates and 0.25 $\mathrm{M} \mathrm{NH}_{2} \mathrm{OH} . \mathrm{HCl}$ in $0.25 \mathrm{M} \mathrm{HCl}$ at $50^{\circ} \mathrm{C}$ for $0.5 \mathrm{~h}$ (Chao and Zhou, 1983), The poorly crystalline iron 3 MPoorly crystalline Fe forms ${ }_{3 \mathrm{M}-\mathrm{HCl}}$ were extracted by equilibrating the sediments with $3 \mathrm{M} \mathrm{HCl}$ for $24 \mathrm{~h}$ (Fredrickson et al., 1998; Stookey, 1970), and total iron ( $\left.\mathrm{Fe}_{\text {Total }}\right)$ extracted using concentrated nitric acid $\left(\mathrm{HNO}_{3}\right)$ and hydrogen peroxide $\left(\mathrm{H}_{2} \mathrm{O}_{2}\right)$ microwave digestion on a MARS XPress microwave (CEM Corporation, Matthews, NC USA). The SSR for all the extractions were $\approx 1: 10$.

\subsection{Statistical analyses}

Statistical analysis of collected data were carried out in Microsoft Excel and Origin Pro 2019b software. Data were tested for normal distribution and homogeneity of variance. Mean and standard deviation were calculated for replicate data. Pearson correlation co-efficient were performed to statistically analyze the data for correlations and significance was considered at $p<0.01$ value.

\section{Result and discussion}

\subsection{Occurrence of $A s(I I I)$ and $A s(V)$}

Fig. 2 illustrates the concentration and distribution of arsenic species in groundwater and stream samples. Dissolved arsenic ranged from 3-18 $\mu \mathrm{g} \mathrm{L}^{-1}$ with highest levels occurring in the groundwater samples. Reduced As(III) species were detected mostly in groundwater but also comprised about $41 \%$ of the arsenic content $\left(\sim 16.0 \mu \mathrm{g} \mathrm{L}^{-1}, \sim 9.6\right.$ $\mathrm{As}(\mathrm{V}) \mu \mathrm{g} \mathrm{\textrm {L } ^ { - 1 }}$ and $\left.\sim 6.4 \mathrm{As}(\mathrm{III}) \mu \mathrm{g} \mathrm{L}^{-1}\right)$ at the Frenchman creek headwater. Reduced As(III) was absent in rest of the creek location (Fig. 2), even $5 \mathrm{~m}$ away from the headwater of Frenchman creek (FC-HW-5 m). Reduced As(III) was detected in about $50 \%$ of groundwater samples and comprising roughly $10-50 \%$ of measured arsenic (Fig. 2). 


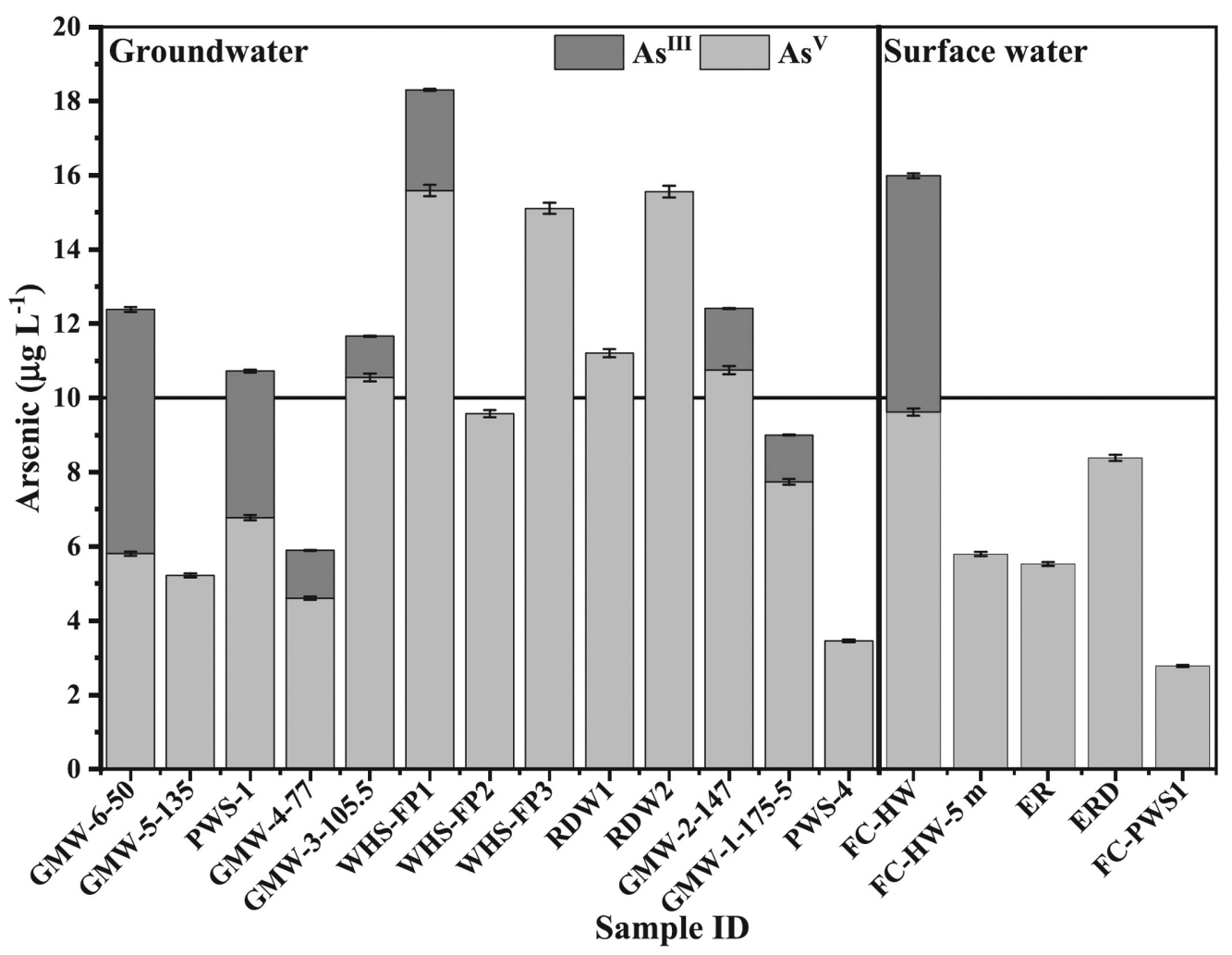

Fig. 2. Concentrations of arsenic species with variability in groundwater and surface water samples collected at Wauneta, NE. GMW: Groundwater monitoring well; PWS: Public water supply; WHS: Wauneta High School; RDW: Recovery Well; FCHW: Frenchman creek-Headwater; ER: Enders' Reservoir; FCPWS1: Frenchman creek near PWS1. Sampling was carried out in 2016 and multiple samples were collected from different monitoring wells in a single location. The horizontal line at $10 \mu \mathrm{g} \mathrm{L}^{-1}$ is maximum contamination level for arsenic in drinking water.

The upstream gaining stretch of Frenchman's creek is influenced by groundwater inflow and likely receives reduced As(III) species by way of groundwater or diffusion from streambed sediments (Fig. 3a). The occurrence and short term stability of As(III) at the headwaters may be supported by reducing conditions (ORP $=-192.9 \mathrm{mV}$; Table S2), and elevated levels of dissolved organic carbon in the headwater of the creek (10.8 mg-C L-1, Table S3). Instream processes and watershed processes can elevate organic carbon content in streams (Mulholland, 1997), and is likely contributing dissolved organic carbon to the headwater of the creek. The significant concentration and proportion of As(III) in the surface water is unexpected, as As(III) should 
readily oxidize to $\mathrm{As}(\mathrm{V})$ in surface water. The proportion of $\mathrm{As}(\mathrm{III})$ is not sustained at sampling locations downstream where arsenic was found to be entirely oxidized (Fig. 2). In contrast, approximately 50\% of the groundwater samples from GMW-6-50, PWS-1, GMW-4-77, GMW-3-105.5, GMW-2-147 and GMW-1-175-5, contained measurable As(III). GMW-6-50 and PWS-1 had 53\% and 37\% As(III) of the total arsenic content (Fig. 2). Further, As(III) in several wells, specifically GMW-5-135 located at the same vicinity as PWS1 and GMW-6-50, was below the detection limit.

Groundwater chemistry is predominantly of $\mathrm{Ca}-\mathrm{Mg}-\mathrm{HCO}_{3}$ type (Fig. S2) with a systematic difference between gaining and losing sides of the stream. Groundwater collected from the northeast side of creek were $\mathrm{Ca}-\mathrm{HCO}_{3}$ type whereas samples from southwest were $\mathrm{Mg}-\mathrm{HCO}_{3}$ type. The $\mathrm{pH}$ of groundwater was in the range of $7.2-8.3$, most of $\mathrm{pH}$ values were close to 7.5. DOC concentrations ranged between 0.5 and $5.4 \mathrm{mg}-\mathrm{C} \mathrm{L}^{-1}$ in the groundwater samples, and the headwaters of Frenchman creek contained much higher concentrations, up to 10.8 mg- C L ${ }^{-1}$ (Table S3).

The total acid-leachable arsenic concentrations in sediment samples were high but generally less than $1553 \mathrm{\mu g} \mathrm{kg}^{-1}$, except at Frenchman creek, where the creek bed sediments concentration of arsenic was close to $4218 \mu \mathrm{g} \mathrm{kg}^{-1}$ (Fig. 3(a-d)). The enrichment in the streambed suggests that the bottom sediments of Frenchman creek may serve as a local sink for arsenic. mobile arsenic varied from 16\% to $71 \%$ of the total arsenic present in the sediments (Fig. 3e). PWS1 sediments had $71 \%$ of arsenic in mobile form, which was followed by Frenchman creek bed sediments at 45\%. Further, both these sites (PWS1 and Frenchman creek) sediments mobile arsenic had As(III) as the major species ( 68\%), with PWS1 sediments containing almost $87 \%$ of As(III). PWS1 sediments were followed by Frenchman creek sediment at $3.3 \mathrm{~m}$ depth (76\%) and PWS4 sediment at depth 34.7 $\mathrm{m}(68 \%)$. It is interesting to see similar As(III) concentration in sediment samples at the water level (PWS1-A, $5.8 \mathrm{~m}$ ) and deeper cores (PWS1-B, $34.4 \mathrm{~m}$ ) for PWS1. In contrast, PWS4 samples at water level (PWS4-A, $18.9 \mathrm{~m}$ ) shows higher $\mathrm{As}(\mathrm{V})$ concentration compared to PWS4-B at $34.7 \mathrm{~m}$ depth, which is comparable to that of PWS1-B at similar depth $(34.4 \mathrm{~m})$. The higher levels of reduced arsenic in the sediments of creek bed and PWS1, which may primarily feed water 

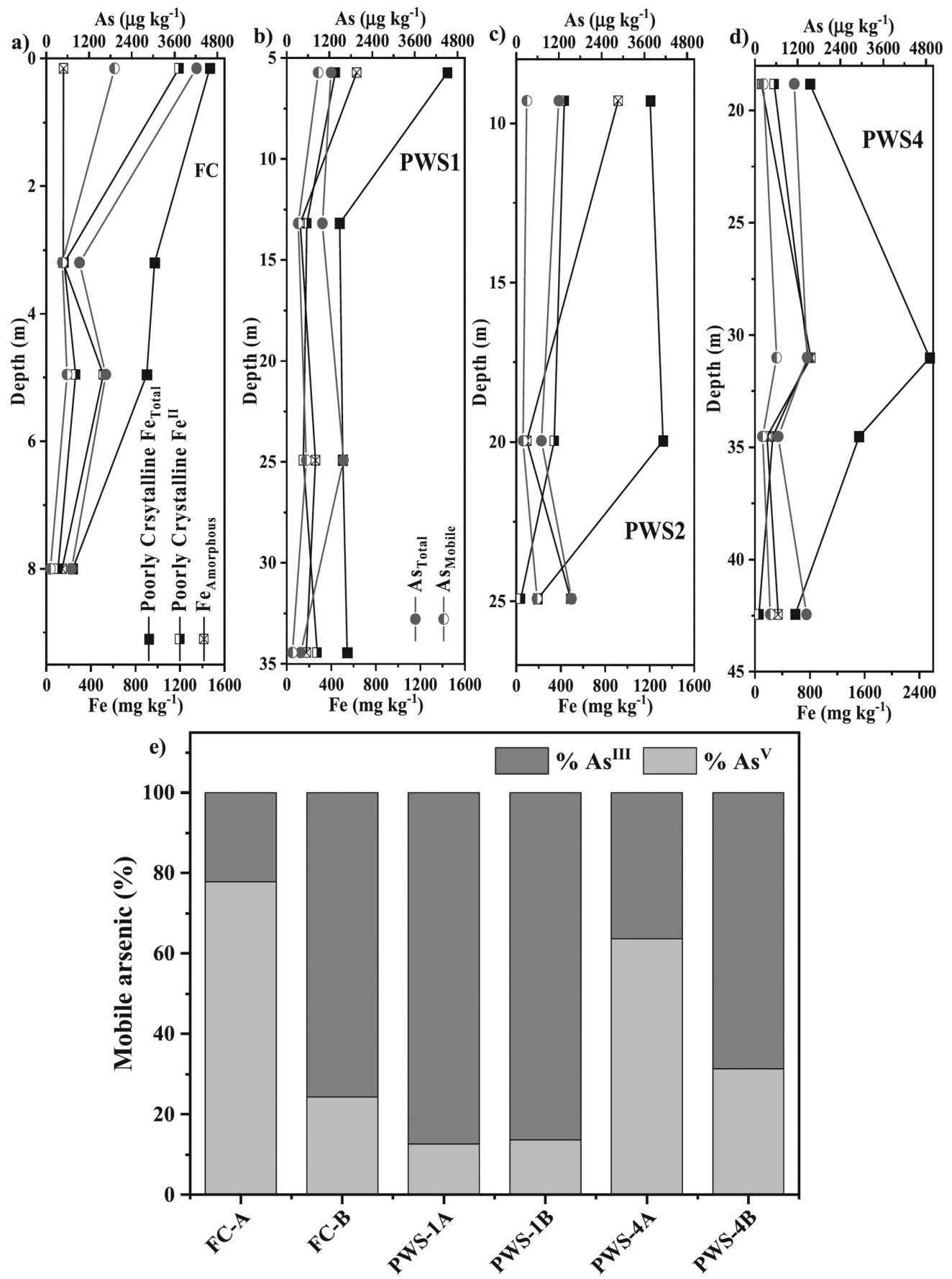

Site ID

Fig. 3. Concentration of Arsenic $\mathrm{Total}$ Arsenic $_{\text {Mobile' }^{\prime}}$ Poorly crystalline Iron $\mathrm{Fe}_{3 \mathrm{M}-\mathrm{HCl}}$ Poorly crystalline reduced iron (Fe(II)), and Amorphous iron in the saturated sediments of a) Frenchman creek, b)PWS1, c)PWS2 and d) PWS4. e) Shows the fraction of As(III) and As(V) present in the $\mathrm{As}_{\text {Mobile }}$ phase of depth specific sediments from $\mathrm{FC}-\mathrm{A}$ at depth $0.03 \mathrm{~m}$ (sediment bed sample) and FC-B at $3.3 \mathrm{~m}$ depth (deeper sediment sample for understanding surface and groundwater interaction), PWS-1A at $5.8 \mathrm{~m}$ depth just above the water table and PWS-1B at $34.4 \mathrm{~m}$ depth for deeper sediment and PWS-4A at $18.9 \mathrm{~m}$ depth just above the water level and PWS-4B at $34.7 \mathrm{~m}$ depth for deeper sediments similar to PWS1. Mean values of three replicates are shown and error bar represents standard deviation. 
to Frenchman creek (Fig. 1b), can serve as the source of arsenite for the surface headwater of the creek.

The proportion of solid-phase Fe(II) ( $>80 \%$ of Poorly crystalline $\mathrm{Fe}_{3 \mathrm{M}-\mathrm{HCl}}$ and $\left.>21 \% \mathrm{Fe}_{\text {Total }}\right)$ was also highest in the Frenchman creek sediment bed sample (Fig. 3a, Table S2), and high levels of solid-phase $\mathrm{Fe}(\mathrm{II})$ is also consistent with reducing conditions in creek bed. ORP fluctuated between 207.7 to $-332.0 \mathrm{mV}$ throughout the depth profile of Frenchman creek, with intermittent positive and negative ORP's in between, indicating redox hotspots with unique anoxic-oxic-anoxicoxic layers within the sediments (Table S3). The pH of the Frenchman creek sediments averaged $6.5 \pm 0.3$, similar to other sediments.

\subsection{Mobility of sediment-bound arsenic}

This location differs from other well-studied high arsenic surface and groundwater systems due to the inflow of iron-rich groundwater upstream and the influence of reducing sediments within a creek bed (Table S2). Sediment geochemical analyses (Fe, Fe(II) and arsenic) revealed two compartments of easily-mobilized arsenic: (1) arsenic derived from Frenchman creek and (2) arsenic sourced from the aquifer sediments (Fig. 4). Sequential extraction was used to help identify the primary arsenic reservoirs and processes. Measurement of the partition coefficient $\left(K_{d}\right)$ helps characterize mobility of arsenic (Tessier et al., 1979). Sequential extraction procedure was carried out in five "operationally defined phases," on sediment samples to study the phase distribution of arsenic and thus understand the sediment-water interaction induced arsenic mobilization in the groundwater.

The overall sequential extraction results suggest that arsenic is being mobilized from stream bed sediments of Frenchman creek as well as aquifer sediments. Sediment samples exhibit total arsenic in the range of $0.39-4.22 \mathrm{mg} \mathrm{kg}^{-1}$ with a potential to further leach $8.3-99.75$ $\mu \mathrm{g} \mathrm{L}^{-1}$ of arsenic to the groundwater (Fig. 4a). Further, mobile arsenic fractions has a significantly strong positive correlation with $\mathrm{Fe}(\mathrm{II})(r=$ $0.77, p<0.01$ ), which may indicate the reductive dissolution of biogenic crystalline iron minerals containing arsenic such as, arsenic adsorbed iron(oxyhydr)oxides, as the principal source of mobile arsenic (Fig. 4a). Two different partition coefficients $\mathrm{K}_{\mathrm{d} 1}$ and $\mathrm{K}_{\mathrm{d} 2}$ were calculated using sum of arsenic fractions I \& II and groundwater arsenic 


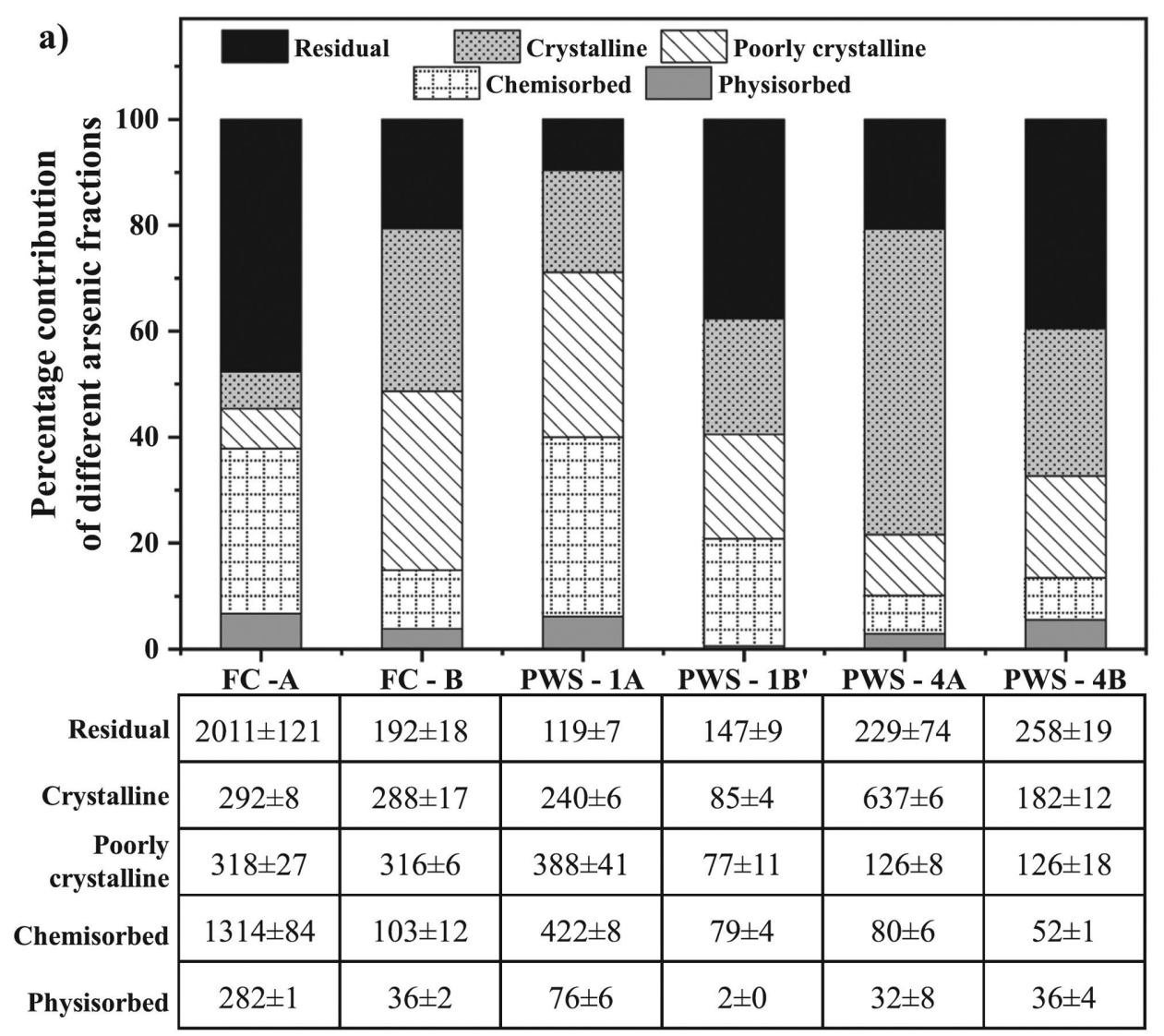

b)

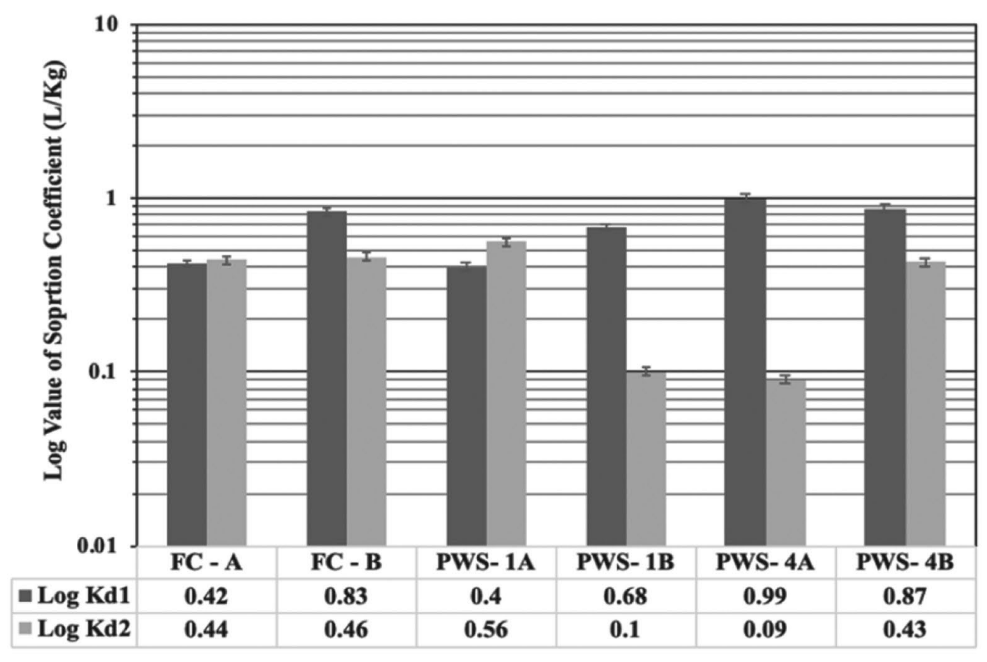

Fig. 4. (a) Results of selective arsenic extractions fractionating total arsenic present in the sediment into weakly adsorbed (Physisorbed), strongly adsorbed (Chemisorbed), poorly crystalline iron or aluminum oxides, well crystalline iron or manganese oxides, and in residual phases (mean $(\mathrm{n}=3) \pm$ standard deviation $\left(\mu \mathrm{g} \mathrm{kg}^{-1}\right)$ ) in six samples are tabulated. Percentage composition, shown in figure, of different fractions indicate the presence of more than $50 \%$ of potential mobile pool (without residual). (b) Leaching potential of arsenic demonstrated by partitioning coefficient $\left(K_{d}\right)$ for six samples $(n=3) .4$ A) 
level of the corresponding sites as the concentration in liquid $\left(C_{L}\right)$ respectively. Most of the sites (other than PWS-1B (34.4 m depth) \& 4 A (18.8 $\mathrm{m}$ depth)) showed good agreement between both $\mathrm{K}_{d}$ which imply that first two fractions of arsenic in the sediment govern arsenic concentrations in the groundwater (Fig. 4b).

Desorption experiments were carried out on selected sediments from Frenchman creek (FC-A, B), PWS 1A, B, and 4A, B. Frenchman creek bed sediment showed higher desorption rate (Fig. S3), which was almost 2-5 times higher than other sediment samples. PWS-1A sample at $5.8 \mathrm{~m}$ depth also showed relatively higher desorption (1.21.8 times) of arsenic compared to rest of the samples, however it was half than Frenchman creek bed (FC-A, 0.03 m) sediment. PWS 4 samples showed the least tendency to lose arsenic from its sediments, although these samples had comparable amount of arsenic present in the sediments, subsequently PWS 4 groundwater samples had less amount of arsenic. These results indicate that the tendency of releasing arsenic from the sediments is enhanced in the Frenchman creek sediment bed samples, which is well-supported by the elevated arsenic concentration in the creek water sample.

Arsenic species, $\mathrm{As}(\mathrm{V})$ or $\mathrm{As}(\mathrm{III})$, is known to be dominant based on the changes in surface-groundwater gradients and Fe(II) and $\mathrm{As}(\mathrm{III})$ generally co-occur, depending on changes in water level and water chemistry of aquifer (Nadakavukaren et al., 1984; Schaefer et al., 2016). The presence of $\mathrm{As}(\mathrm{III})$ at the stream headwater may be due to prevalence of iron-rich clays (Cuadros, 2017; Hofstetter et al., 2003; Kostka et al., 2002; Mensah et al., 2020) at a location heavily influenced by groundwater inflow (Ernstsen et al., 1998). After entering the stream environment, arsenic is slowly oxidized and readily absorbed in carbonate-rich bed sediments (Romero et al., 2004). Reduced As(III) has previously been reported in carbonate-rich groundwater, where Fe(II) partitions in carbonate cements (Szramek et al., 2004). Other mechanisms of arsenic release in this system includes reductive dissolution of As(III)-bearing iron oxides by biotic processes or by chemical weathering of arsenic-enriched sedimentary layers followed by subsequent direct reduction of $A s(V)$ to $A s(I I I)$, sulfur redox reactions occurring in saturated and unsaturated conditions can also impact arsenic availability (Laing et al., 2009; Mensah et al., 2020). Given the preponderance of elevated As(III) in stream bed sediments, reductive dissolution and release of arsenic into the stream water is more likely. 


\subsection{Conceptual hypothesis for occurrence of As(III) in surface water}

Interestingly, As(III) species was found to be prevalent in the headwaters of Frenchman creek. The unique observation at the present study site provides an example where reduced As(III) can occur and persist in an aerobic surface water environment. The creek bed sediments presented distinctive oxic-anoxic zones, and partition co-efficient values point to elevated arsenic leaching potential from creek bed sediments indicating considerable concentration of mobile arsenic. The mobile arsenic pool presumably governs the concentration of arsenic in the surface and groundwater. Further, the interaction of surface water and groundwater at the headwater site of Frenchman creek controlled arsenic mobilization and sustained redox-sensitive species.

A conceptual model depicting the mechanism of arsenic in the current study area has been proposed (Fig. 5). It appears, the dynamic nature of surface water - groundwater interaction at the headwater of the creek can increase arsenic concentration at the study area. Reductive dissolution of iron-(oxyhydr)oxide minerals in creek bed, which serves as the redox hotspot, releases $A s(V)$ which is subsequently reduced to As (III) (Langner and Inskeep, 2000). This is suggested by equilibrating the sediments with artificial groundwater (100 $\mathrm{g} / \mathrm{l}$ sediment:liquid ratio) for $24 \mathrm{~h}$, which resulted in $\sim 11.1 \pm 1.2 \mu \mathrm{g}$ $\mathrm{L}^{-1}$ arsenic $\left(\sim 8.6 \pm 0.9 \mu \mathrm{g} \mathrm{L}^{-1} \mathrm{As}(\mathrm{V})\right.$ and $\left.\sim 2.5 \pm 1.6 \mu \mathrm{g} \mathrm{L}^{-1} \mathrm{As}(\mathrm{III})\right)$. The redox fluctuation and interaction with $\mathrm{DOC}$ is known to impact arsenic geochemistry (El-Naggar et al., 2019; Frohne et al., 2011; Lemonte et al., 2017). Reducing conditions in freshwater soil is known to release arsenic as a function of iron minerals and DOC (Shaheen et al., 2016). Similar processes of releasing arsenic may be active in the creek bed sediments which contained high arsenic. Prevalent redox hotspots in the creek sediment bed, with distinct anoxic-oxic-anoxicoxic layers within the creek sediments, can initiate reductive dissolution of arsenic-bearing mineral oxides. As(III) in creek bed can interact with groundwater through mixing in the hyporheic zone, with the blue arrows denoting the direction of groundwater flow and may impact arsenic concentration in groundwater. As(III) may later be oxidized to $\operatorname{As}(\mathrm{V})$, which may be due to microbial activity or due to the presence of dissolved oxygen in the stream or porewater in the soil. Arsenic-rich groundwater can be another probable source of arsenic when it feeds the headwater of the creek (blue dashed arrows), high 


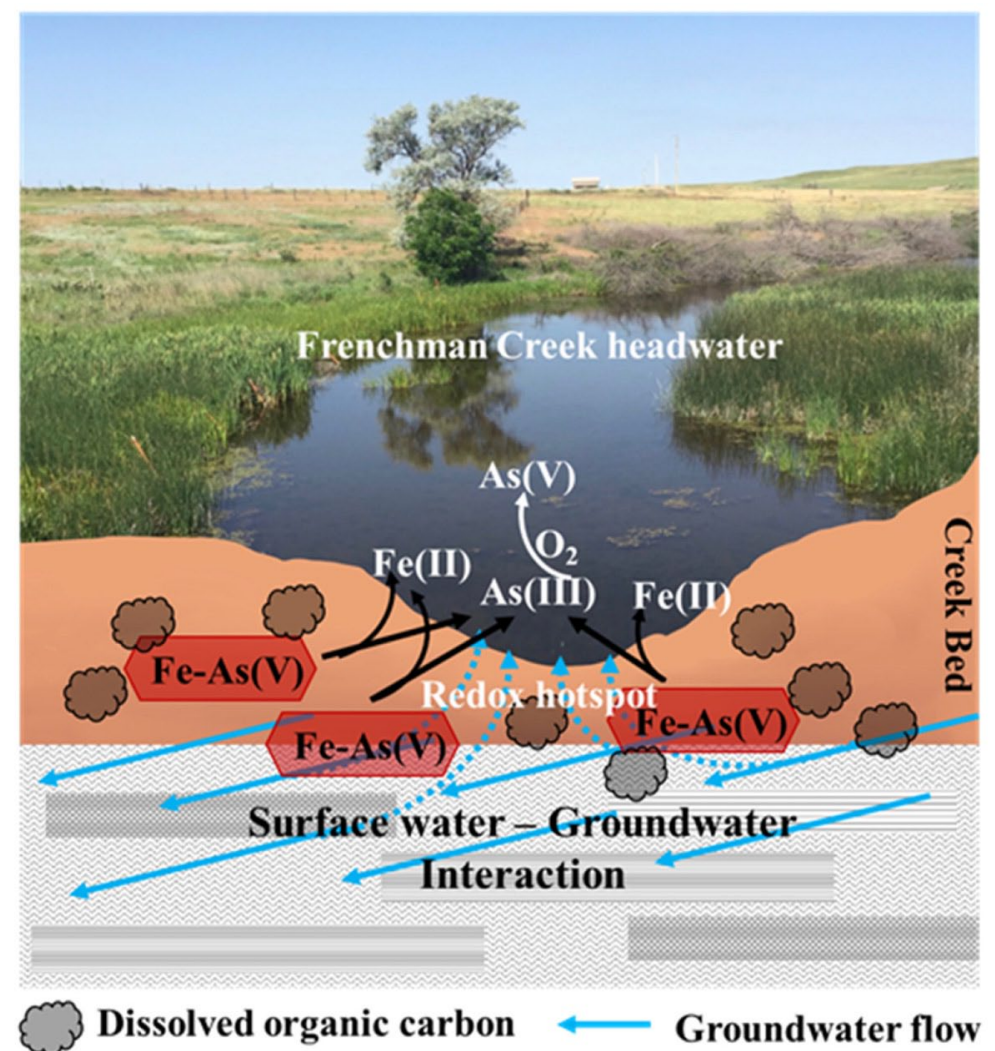

Fig. 5. Proposed conceptual model of arsenic release into the headwater of the Frenchman creek at the study sites. Abiotic and/or biotic mediated reductive dissolution of iron-(hydr)oxide mineral surfaces in the creek bed of Frenchman creek and groundwater-surface water interactions seems to be the main processes occurring in the aquifers of Wauneta, which can help in sustaining reduced arsenic in the surface headwater of the creek.

DOC content most likely promotes microbial respiration. Inflow of iron-rich groundwater will help maintain reducing conditions favoring the occurrence of $\mathrm{As}$ (III) prevalent in stream environment and the creek bed, which is evident from elevated levels of Fe (II).

\section{Conclusion}

We have traced the imprints of arsenic speciation in the water and sediment to understand the groundwater-surface water interactions and its implication. The headwaters of Frenchman creek, a gaining stream that crosses the Colorado-Nebraska border, provided an 
excellent set up for the investigation that lead to detection of reduced arsenic species, contrary to more prevalent situation of its oxidative state. It has been further confirmed through selective dissolution extraction analysis of aquifer and stream bed sediments exhibiting the presence of a bulk of the labile iron-rich oxy(hydroxide) minerals imbedded with arsenite. The presence of over one third of reduced arsenic in the surface and groundwater is threatening considering its toxicity and indicative of clay and rich organic matter induced creation of anoxic environment. Overall, the occurrence of persistent and mobile $\mathrm{As}(\mathrm{III})$ in a gaining stream is relatively novel and the co-occurrence of reduced iron- (oxyhydr)oxides in likely maintaining reduced zones along the lower reaches of Frenchman creek, which has several environmental and health implications. The long-term influence of groundwater - surface water interaction in this region likely sustains reducing conditions and may stabilize reduced arsenic in the surface headwater. Although, further investigation will require through characterization of the microbial population and abiotic facilitated mobilization of the sediment fractions, evaluation of surface-complexation and use of isotope tracers to explore the mechanics of arsenic enrichment and mobilization. It is very certain that in arsenic hotspots areas not only groundwater threatens the human population, but such small drains, creeks, lakes and other surface waters that are often used for irrigation, can cause much toxicity through being accumulated by staple food and vegetables. The present observation can be extrapolated to other similar hydrological setup, where surface water and groundwater interacts and can be prevalent around the globe with similar conditions, stabilizing reduced trace element species in surface water environment.

CRediT authorship contribution statement Arindam Malakar: Investigation, Formal analysis, Visualization, Writing - original draft, Writing - review \& editing. Rajesh Singh: Investigation, Resources, Visualization, Writing - original draft. Karrie A. Weber: Conceptualization, Supervision, Writing - review \& editing, Funding acquisition. Jeffrey Westrop: Investigation, Visualization, Writing - original draft. Christopher N. Elofson: Investigation, Writing - original draft. Manish Kumar: Investigation, Writing - review \& editing, Visualization. Daniel D. Snow: Conceptualization, Supervision, Writing - review \& editing, Funding acquisition, Project administration. 
Competing Interests The authors declare that they have no known competing financial interests or personal relationships that could have appeared to influence the work reported in this paper.

Acknowledgments The authors appreciate the financial support from Tom Christopherson, Groundwater Solutions Group (Yutan, NE USA), for the costs associated with the geochemical analysis. We also want to acknowledge Bo Bonn and Gregg Philips from Geospec Drilling (Gretna, NE USA) for assistance in acquiring geological sediments and also for providing core descriptions presented in Fig. 1b. AM, RS, and MK would like to thank Department of Science and Technology (DST) New Delhi, India, Indo-US Science and Technology Forum (IUSSTF) New Delhi, India, and University of Nebraska Daugherty Water for Food Institute, Lincoln Nebraska USA for Water Advanced Research and Innovation (WARI) internship and fellowship funds to carry out the research. Partial support for this project was from USGS $104104 \mathrm{~g}$ Program Grant 2014NE265G awarded to KW and DS. Authors thank the staff of Water Sciences Laboratory, University of Nebraska Lincoln for chemical analysis of samples.

Supporting information Supplementary data follows the References and is also attached to the archive record for this document.

\section{References}

Aparicio, E., Vargas, M.J., Olmo, J.M., de Sostoa, A., 2000. Decline of native freshwater fishes in a Mediterranean watershed on the Iberian peninsula: a quantitative assessment. Environ. Biol. Fish. https://doi. org/10.1023/A:1007618517557

Bissen, M., Frimmel, F.H., 2003. Arsenic - a review. Part I: occurrence, toxicity, speciation, mobility. Acta Hydrochim. Hydrobiol. 31, 9-18. https://doi. org/10.1002/aheh.200390025

Cardwell, W.D.E., Jenkins, E.D., 1963. Ground-water geology and pump irrigation in Frenchman Creek Basin above Palisade, Nebraska. Water Supply Pap. 1577, 472. http://pubs.er.usgs.gov/publication/wsp1577

Chao, T.T., Zhou, L., 1983. Extraction techniques for selective dissolution of amorphous iron oxides from soils and sediments. Soil Sci. Soc. Am. J. 47, 225 232. https://doi.org/10.2136/sssaj1983.03615995004700020010x

Cuadros, J., 2017. Clay minerals interaction with microorganisms: a review. Clay Min. 52, 235-261. https://doi.org/10.1180/claymin.2017.052.2.05

von der Heyden, B.P., Roychoudhury, A.N., 2015. Application, chemical interaction and fate of iron minerals in polluted sediment and soils. Curr. Pollut. Rep. 1, 265-279. https://doi.org/10.1007/s40726-015-0020-2

Ding, W., Xu, J., Chen, T., Liu, C., Li, J., Wu, F., 2018. Co-oxidation of As(III) and Fe(II) by oxygen through complexation between $\mathrm{As}(\mathrm{III})$ and $\mathrm{Fe}(\mathrm{II}) / \mathrm{Fe}(\mathrm{III})$ species. Water Res. 143, 599-607. https://doi.org/10.1016/j.watres.2018.06.072 
Dixit, S., Hering, J.G., 2003. Comparison of arsenic(V) and arsenic(III) sorption onto iron oxide minerals: implications for arsenic mobility. Environ. Sci. Technol. 37, 4182-4189. https://doi.org/10.1021/es030309t

El-Naggar, A., Shaheen, S.M., Hseu, Z.Y., Wang, S.L., Ok, Y.S., Rinklebe, J., 2019. Release dynamics of $\mathrm{As}, \mathrm{Co}$, and $\mathrm{Mo}$ in a biochar treated soil under pre-definite redox conditions. Sci. Total Environ. 657, 686-695. https://doi.org/10.1016/j. scitotenv.2018.12.026

Ernstsen, V., Gates, W.P., Stucki, J.W., 1998. Microbial reduction of structural iron in clays - a renewable source of reduction capacity. J. Environ. Qual. 27, 761-766. https://doi.org/10.2134/jeg1998.00472425002700040006x

Fan, J.X., Wang, Y.J., Liu, C., Wang, L.H., Yang, K., Zhou, D.M., Li, W., Sparks, D.L., 2014. Effect of iron oxide reductive dissolution on the transformation and immobilization of arsenic in soils: new insights from X-ray photoelectron and X-ray absorption spectroscopy. J. Hazard. Mater. 279, 212-219. https://doi. org/10.1016/j.jhazmat.2014.06.079

Fendorf, S., Michael, H.A., Van Geen, A., 2010. Spatial and temporal variations of groundwater arsenic in South and Southeast Asia. Science 328, 1123-1127. https://doi.org/10.1126/science.1172974

Fredrickson, J.K., Zachara, J.M., Kennedy, D.W., Dong, H., Onstott, T.C., Hinman, N.W., Li, S., 1998. Biogenic iron mineralization accompanying the dissimilatory reduction of hydrous ferric oxide by a groundwater bacterium. Geochim. Cosmochim. Acta 62, 3239-3257. https://doi.org/10.1016/ S0016-7037(98)00243-9

Frohne, T., Rinklebe, J., Diaz-Bone, R.A., Laing, G.D., 2011. Controlled variation of redox conditions in a floodplain soil: Impact on metal mobilization and biomethylation of arsenic and antimony. Geoderma 160, 414-424. https://doi. org/10.1016/j.geoderma.2010.10.012

Geospec Drilling, 2016. Wauneta Cross Section. Normal Resistivity Curves. Wauneta, Nebraska. [Unpublished Report, 07/13/16].

Gosselin, D.C., Klawer, L.M., Joeckel, R.M., Harvey, F.E., Reade, A.R., McVey, K., 2006. Arsenic in groundwater and rural public water supplies in Nebraska, U.S.A. Gt. Plains Res. 16, 137-148. http://digitalcommons.unl.edu/ greatplainsresearch $/ 848$

Hafeznezami, S., Zimmer-Faust, A.G., Dunne, A., Tran, T., Yang, C., Lam, J.R., Reynolds, M.D., Davis, J.A., Jay, J.A., 2016. Adsorption and desorption of arsenate on sandy sediments from contaminated and uncontaminated saturated zones: kinetic and equilibrium modeling. Environ. Pollut. 215, 290301. https://doi.org/10.1016/j.envpol.2016.05.029

Hamon, R.E., Lombi, E., Fortunati, P., Nolan, A.L., McLaughlin, M.J., 2004. Coupling speciation and isotope dilution techniques to study arsenic mobilization in the environment. Environ. Sci. Technol. 38, 1794-1798. https://doi.org/10.1021/ es034931x

Haque, S., Ji, J., Johannesson, K.H., 2008. Evaluating mobilization and transport of arsenic in sediments and groundwaters of Aquia aquifer, Maryland, USA. J. Contam. Hydrol. 99, 68-84. https://doi.org/10.1016/j.jconhyd.2008.03.003 
Herbel, M., Fendorf, S., 2006. Biogeochemical processes controlling the speciation and transport of arsenic within iron coated sands. Chem. Geol. 228, 16-32. https://doi.org/10.1016/j.chemgeo.2005.11.016

Hofstetter, T.B., Schwarzenbach, R.P., Haderlein, S.B., 2003. Reactivity of Fe(II) species associated with clay minerals. Environ. Sci. Technol. 37, 519-528. https://doi.org/10.1021/es025955r

Ilbert, M., Bonnefoy, V., 2013. Insight into the evolution of the iron oxidation pathways. Biochim. Biophys. Acta BBA Bioenerg. 1827, 161-175. https://doi. org/10.1016/j.bbabio.2012.10.001

Kocar, B.D., Fendorf, S., 2009. Thermodynamic constraints on reductive reactions influencing the biogeochemistry of arsenic in soils and sediments. Environ. Sci. Technol. 43, 4871-4877. https://doi.org/10.1021/es8035384

Kohler, M., Curtis, G.P., Meece, D.E., Davis, J.A., 2004. Methods for estimating adsorbed Uranium( $\mathrm{VI})$ and distribution coefficients of contaminated sediments. Environ. Sci. Technol. 38, 240-247. https://doi.org/10.1021/es0341236

Kostka, J.E., Dalton, D.D., Skelton, H., Dollhopf, S., Stucki, J.W., 2002. Growth of iron (III)-reducing bacteria on clay minerals as the sole electron acceptor and comparison of growth yields on a variety of oxidized iron forms. Appl. Environ. Microbiol. 68, 6256-6262. https://doi.org/10.1128/AEM.68.12.6256-6262.2002

Krupka, K.M., Kaplan, D.I., Whelan, G., Serne, R.J., Mattigod, S.V. (1999). Understanding variation in partition coefficient, $\mathrm{Kd}$, values. Volume III: Review of Geochemistry and Available Kd Values for Americium, Arsenic, Curium, lodine, Neptunium, Radium, and Technetium. EPA, 402-R-99-004A.

Laing, G. Du, Chapagain, S.K., Dewispelaere, M., Meers, E., Kazama, F., Tack, F.M.G., Rinklebe, J., Verloo, M.G., 2009. Presence and mobility of arsenic in estuarine wetland soils of the Scheldt estuary (Belgium). J. Environ. Monit. 11, 873-881. https://doi.org/10.1039/b815875d

Langner, H.W., Inskeep, W.P., 2000. Microbial reduction of arsenate in the presence of ferrihydrite. Environ. Sci. Technol. 34, 3131-3136. https://doi.org/10.1021/ es991414z

Lemonte, J.J., Stuckey, J.W., Sanchez, J.Z., Tappero, R., Rinklebe, J., Sparks, D.L., 2017. Sea level rise induced arsenic release from historically contaminated coastal soils. Environ. Sci. Technol. 51, 5913-5922. https://doi.org/10.1021/acs. est.6b06152

Mackay, A.A., Gan, P., Yu, R., Smets, B.F., 2014. Seasonal arsenic accumulation in stream sediments at a groundwater discharge zone. Environ. Sci. Technol. 48, 920-929. https://doi.org/10.1021/es402552u

Malakar, A., Das, B., Islam, S., Meneghini, C., De Giudici, G., Merlini, M., Kolen'ko, Y.V., ladecola, A., Aquilanti, G., Acharya, S., Ray, S., 2016. Efficient artificial mineralization route to decontaminate Arsenic(III) polluted water - the tooeleite way. Sci. Rep. 6, 26031. https://doi.org/10.1038/srep26031

Malakar, A., Islam, S., Ali, M.A., Ray, S., 2016. Rapid decadal evolution in the groundwater arsenic content of Kolkata, India and its correlation with the practices of her dwellers. Environ. Monit. Assess. 188, 1-22. https://doi. org/10.1007/s10661-016-5592-9 
Malakar, A., Kaiser, M., Snow, D.D., Walia, H., Panda, B., Ray, C., 2020. Ferrihydrite reduction increases arsenic and uranium bioavailability in unsaturated soil. Environ. Sci. Technol. 54, 13839-13848. https://doi.org/10.1021/acs.est.0c02670

Melton, E.D., Swanner, E.D., Behrens, S., Schmidt, C., Kappler, A., 2014. The interplay of microbially mediated and abiotic reactions in the biogeochemical Fe cycle. Nat. Rev. Microbiol. 12, 797-808. https://doi.org/10.1038/nrmicro3347

Mensah, A.K., Marschner, B., Shaheen, S.M., Wang, J., Wang, S.L., Rinklebe, J., 2020. Arsenic contamination in abandoned and active gold mine spoils in Ghana: geochemical fractionation, speciation, and assessment of the potential human health risk. Environ. Pollut. 261, 114116 https://doi.org/10.1016/j. envpol.2020.114116

Miot, J., Etique, M., 2016. Formation and transformation of iron-bearing minerals by iron(II)-oxidizing and iron(III)-reducing bacteria. In: Iron Oxides. WileyVCH Verlag GmbH \& Co. KGaA, Weinheim, Germany, pp. 53-98. https://doi. org/10.1002/9783527691395.ch4

Missimer, T.M., Teaf, C.M., Beeson, W.T., Maliva, R.G., Woolschlager, J., Covert, D.J., 2018. Natural background and anthropogenic arsenic enrichment in Florida soils, surface water, and groundwater: a review with a discussion on public health risk. Int. J. Environ. Res. Public Health 15 (10), 2278. https://doi. org/10.3390/ijerph15102278

Mladenov, N., Zheng, Y., Miller, M.P., Nemergut, D.R., Legg, T., Simone, B., Hageman, C., Rahman, M.M., Ahmed, K.M., McKnight, D.M., 2010. Dissolved organic matter sources and consequences for iron and arsenic mobilization in Bangladesh aquifers. Environ. Sci. Technol. 44, 123-128. https://doi. org/10.1021/es901472g

Mladenov, N., Wolski, P., Hettiarachchi, G.M., Murray-Hudson, M., Enriquez, H., Damaraju, S., Galkaduwa, M.B., McKnight, D.M., Masamba, W., 2014. Abiotic and biotic factors influencing the mobility of arsenic in groundwater of a through-flow island in the Okavango Delta, Botswana. J. Hydrol. 518, 326-341. https://doi.org/10.1016/J.JHYDROL.2013.09.026

Mladenov, N., Zheng, Y., Simone, B., Bilinski, T.M., McKnight, D.M., Nemergut, D., Radloff, K.A., Rahman, M.M., Ahmed, K.M., 2015. Dissolved organic matter quality in a shallow aquifer of Bangladesh: implications for arsenic mobility. Environ. Sci. Technol. 49, 10815-10824. https://doi.org/10.1021/acs. est.5b01962

Mulholland, P.J., 1997. Dissolved organic matter concentration and flux in streams. J. North Am. Benthol. Soc. 16, 131-141. https://doi.org/10.2307/1468246

Nadakavukaren, J.J., Ingermann, R.L., Jeddeloh, G., Falkowski, S.J., 1984. Seasonal variation of arsenic concentration in well water in Lane County, Oregon. Bull. Environ. Contam. Toxicol. 33, 264-269. https://doi.org/10.1007/BF01625541

Neil, C.W., Jun, Y.S., 2016. Fe ${ }^{3+}$ addition promotes arsenopyrite dissolution and Iron(III) (hydr)oxide formation and phase transformation. Environ. Sci. Technol. Lett. 3, 30-35. https://doi.org/10.1021/acs.estlett.5b00311 
Neumann, R.B., Pracht, L.E., Polizzotto, M.L., Badruzzaman, A.B.M., Ali, M.A., 2014. Biodegradable organic carbon in sediments of an arsenic-contaminated aquifer in Bangladesh. Environ. Sci. Technol. Lett. 1, 221-225. https://doi. org/10.1021/ez5000644

Nghiem, A.A., Shen, Y., Stahl, M., Sun, J., Haque, E., DeYoung, B., Nguyen, K.N., Thi Mai, T., Trang, P.T.K., Pham, H.V., Mailloux, B., Harvey, C.F., van Geen, A., Bostick, B.C., 2020. Aquifer-scale observations of iron redox transformations in arsenicimpacted environments to predict future contamination. Environ. Sci. Technol. Lett. 7, 916-922. https://doi.org/10.1021/acs.estlett.0c00672

Nickson, R., McArthur, J., Burgess, W., Ahmed, K.M., Ravenscroft, P., Rahmanñ, M., 1998. Arsenic poisoning of Bangladesh groundwater. Nature 395, 338. https:// doi.org/10.1038/26387

Nickson, R.T., McArthur, J.M., Ravenscroft, P., Burgess, W.G., Ahmed, K.M., 2000. Mechanism of arsenic release to groundwater, Bangladesh and West Bengal. Appl. Geochem. 15, 403-413. https://doi.org/10.1016/S0883-2927(99)00086-4

Ona-Nguema, G., Morin, G., Juillot, F., Calas, G., Brown, G.E., 2005. EXAFS analysis of arsenite adsorption onto two-line ferrihydrite, hematite, goethite, and lepidocrocite. Environ. Sci. Technol. 39, 9147-9155. https://doi.org/10.1021/ es050889p

Ona-Nguema, G., Morin, G., Wang, Y., Menguy, N., Juillot, F., Olivi, L., Aquilanti, G., Abdelmoula, M., Ruby, C., Bargar, J.R., Guyot, F., Calas, G., Brown, G.E., 2009. Arsenite sequestration at the surface of nano- $\mathrm{Fe}(\mathrm{OH})_{2^{\prime}}$, ferrous-carbonate hydroxide, and green-rust after bioreduction of arsenic-sorbed lepidocrocite by Shewanella putrefaciens. Geochim. Cosmochim. Acta 73, 1359-1381. https://doi.org/10.1016/j.gca.2008.12.005

Podgorski, J., Berg, M., 2020. Global threat of arsenic in groundwater. Science 368, 845-850. https://doi.org/10.1126/science.aba1510

Rawson, J., Prommer, H., Siade, A., Carr, J., Berg, M., Davis, J.A., Fendorf, S., 2016. Numerical modeling of arsenic mobility during reductive iron-mineral transformations. Environ. Sci. Technol. 50, 2459-2467. https://doi.org/10.1021/ acs.est.5b05956

Romero, F.M., Armienta, M.A., Carrillo-Chavez, A., 2004. Arsenic sorption by carbonate-rich aquifer material, a control on arsenic mobility at Zimapán, México. Arch. Environ. Contam. Toxicol. 47, 1-13. https://doi.org/10.1007/ s00244-004-3009-1

Rowland, H.A.L., Polya, D.A., Lloyd, J.R., Pancost, R.D., 2006. Characterisation of organic matter in a shallow, reducing, arsenic-rich aquifer, West Bengal. Org. Geochem. 37, 1101-1114. https://doi.org/10.1016/j.orggeochem.2006.04.011

Samanta, G., Clifford, D.A., 2005. Preservation of inorganic arsenic species in groundwater. Environ. Sci. Technol. 39, 8877-8882. https://doi.org/10.1021/ es051185i

Sathe, S.S., Mahanta, C., Mishra, P., 2018. Simultaneous influence of indigenous microorganism along with abiotic factors controlling arsenic mobilization in Brahmaputra floodplain, India. J. Contam. Hydrol. 213, 1-14. https://doi. org/10.1016/j.jconhyd.2018.03.005 
Schaefer, M.V., Ying, S.C., Benner, S.G., Duan, Y., Wang, Y., Fendorf, S., 2016. Aquifer arsenic cycling induced by seasonal hydrologic changes within the Yangtze River basin. Environ. Sci. Technol. 50, 3521-3529. https://doi.org/10.1021/acs. est.5b04986

Shaheen, S.M., Rinklebe, J., Frohne, T., White, J.R., DeLaune, R.D., 2016. Redox effects on release kinetics of arsenic, cadmium, cobalt, and vanadium in Wax Lake Deltaic freshwater marsh soils. Chemosphere 150, 740-748. https://doi. org/10.1016/j.chemosphere.2015.12.043

Shankar, S., Shanker, U., Shikha, 2014. Arsenic contamination of groundwater: a review of sources, prevalence, health risks, and strategies for mitigation. Scientific World Journal 2014, 304524. https://doi.org/10.1155/2014/304524

Singh, S.K., Stern, E.A., 2017. Global arsenic contamination: living with the poison nectar. Environ. Sci. Policy Sustain. Dev. 59, 24-28. https://doi.org/10.1080/0013 $\underline{9157.2017 .1274583}$

Smedley, P.L., Zhang, M., Zhang, G., Luo, Z., 2003. Mobilisation of arsenic and other trace elements in fluviolacustrine aquifers of the Huhhot Basin, Inner Mongolia. Appl. Geochem. 18, 1453-1477. https://doi.org/10.1016/ S0883-2927(03)00062-3

Sorg, T.J., Chen, A.S.C., Wang, L., 2014. Arsenic species in drinking water wells in the USA with high arsenic concentrations. Water Res. 48, 156-169. https:// doi.org/10.1016/j.watres.2013.09.016 Stookey, L.L., 1970. Ferrozine - a new spectrophotometric reagent for iron. Anal. Chem. 42, 779-781. https://doi. org/10.1021/ac60289a016

Straub, K.L., Benz, M., Schink, B., 2001. Iron metabolism in anoxic environments at near neutral pH. FEMS Microbiol. Ecol. 34 (3), 181-186. https://doi. org/10.1016/S0168-6496(00)00088-X

Strawn, D.G., 2018. Review of interactions between phosphorus and arsenic in soils from four case studies. Geochem. Trans. 19, 10. https://doi.org/10.1186/ s12932-018-0055-6

Stubbe, M., Broschewitz, U., Kramm, G., Schmidt, W., Radtke, A., 2011. Analyse der Konisationen im Zeitraum von 2005-2009 in Rostock. In: Geburtshilfe Frauenheilkd. World Health Organization, Geneva, pp. 187-193. https://doi. org/10.1055/s-0030-1270755

Szramek, K., Walter, L.M., McCall, P., 2004. Arsenic mobility in groundwater/ surface water systems in carbonate-rich Pleistocene glacial drift aquifers (Michigan). Appl. Geochem. 19, 1137-1155. https://doi.org/10.1016/j. apgeochem.2004.01.012

Tallman, D.E., Shaikh, A.U., 1980. Redox stability of inorganic arsenic(III) and arsenic (V) in aqueous solution. Anal. Chem. 52, 196-199. https://doi. org/10.1021/ac50051a047

Tessier, A., Campbell, P.G.C., Bisson, M., 1979. Sequential extraction procedure for the speciation of particulate trace metals. Anal. Chem. 51, 844-851. https://doi. org/10.1021/ac50043a017 
Traylor, J.P., Zlotnik, V.A., 2016. Analytical modeling of irrigation and land use effects on streamflow in semi-arid conditions. J. Hydrol. 533, 591-602. https:// doi.org/10.1016/j.jhydrol.2015.12.006

Wang, Y., Morin, G., Ona-Nguema, G., Brown, G.E., 2014. Arsenic(III) and arsenic(V) speciation during transformation of lepidocrocite to magnetite. Environ. Sci. Technol. 48, 14282-14290. https://doi.org/10.1021/es5033629

Wenzel, W.W., Kirchbaumer, N., Prohaska, T., Stingeder, G., Lombi, E., Adriano, D.C., 2001. Arsenic fractionation in soils using an improved sequential extraction procedure. Anal. Chim. Acta 436, 309-323. https://doi.org/10.1016/ S0003-2670(01)00924-2

Whaley-Martin, K.J., Mailloux, B.J., Van Geen, A., Bostick, B.C., Silvern, R.F., Kim, C., Ahmed, K.M., Choudhury, I., Slater, G.F., 2016. Stimulation of microbially mediated arsenic release in Bangladesh aquifers by young carbon indicated by radiocarbon analysis of sedimentary bacterial lipids. Environ. Sci. Technol. 50, 7353-7363. https://doi.org/10.1021/acs.est.6b00868

Wu, D., Pichler, T., 2016. Preservation of co-occurring As, Sb and Se species in water samples with EDTA and acidification. Geochem. Explor. Environ. Anal. 16, 117-125. https://doi.org/10.1144/geochem2015-369

Wu, S., Fang, G., Wang, D., Jaisi, D.P., Cui, P., Wang, R., Wang, Y., Wang, L., Sherman, D. M., Zhou, D., 2018. Fate of As(III) and As(V) during microbial reduction of arsenic-bearing ferrihydrite facilitated by activated carbon. ACS Earth Sp. Chem. 2, 878-887. https://doi.org/10.1021/acsearthspacechem.8b00058

Xie, Q., Kerrich, R., Irving, E., Liber, K., Abou-Shakra, F., 2002. Determination of five arsenic species in aqueous samples by HPLC coupled with a hexapole collision cell ICP-MS. J. Anal. . Spectrom. 17, 1037-1041. https://doi.org/10.1039/ $\underline{\text { b202172b }}$ 


\section{Occurrence of Arsenite in surface and groundwater associated with a perennial stream located in Western Nebraska, USA}

Arindam Malakar ${ }^{1}$, Rajesh Singh ${ }^{2}$, Karrie A. Weber ${ }^{3,4}$, Jeffery Westrop ${ }^{3}$, Christopher N. Elofson ${ }^{3}$, Manish Kumar ${ }^{5}$, Daniel D. Snow,**

${ }^{1}$ Nebraska Water Center, part of the Robert B. Daugherty Water for Food Global Institute, 109 Water Sciences Laboratory, University of Nebraska, Lincoln, NE 68583-0844, USA

${ }^{2}$ Environmental Hydrology Division, National Institute of Hydrology, Roorkee, India

${ }^{3}$ School of Biological Sciences University of Nebraska-Lincoln 232 Manter Hall Lincoln, NE 685880118

${ }^{4}$ Department of Earth and Atmospheric Sciences and Robert B. Daugherty Water for Food Global Institute, University of Nebraska-Lincoln 316 Bessey Hall Lincoln, NE 68588-0340

${ }^{5}$ Discipline of Earth Sciences, Indian Institute of Technology Gandhinagar- 382355, Gujarat, India

${ }^{6}$ School of Natural Resources and Nebraska Water Center, part of the Robert B. Daugherty Water for Food Global Institute, 202 Water Sciences Laboratory, University of Nebraska, Lincoln, NE 685830844, USA

*Corresponding author: Daniel D. Snow Email ID: dsnow1 @unl.edu

\section{Supporting Information}




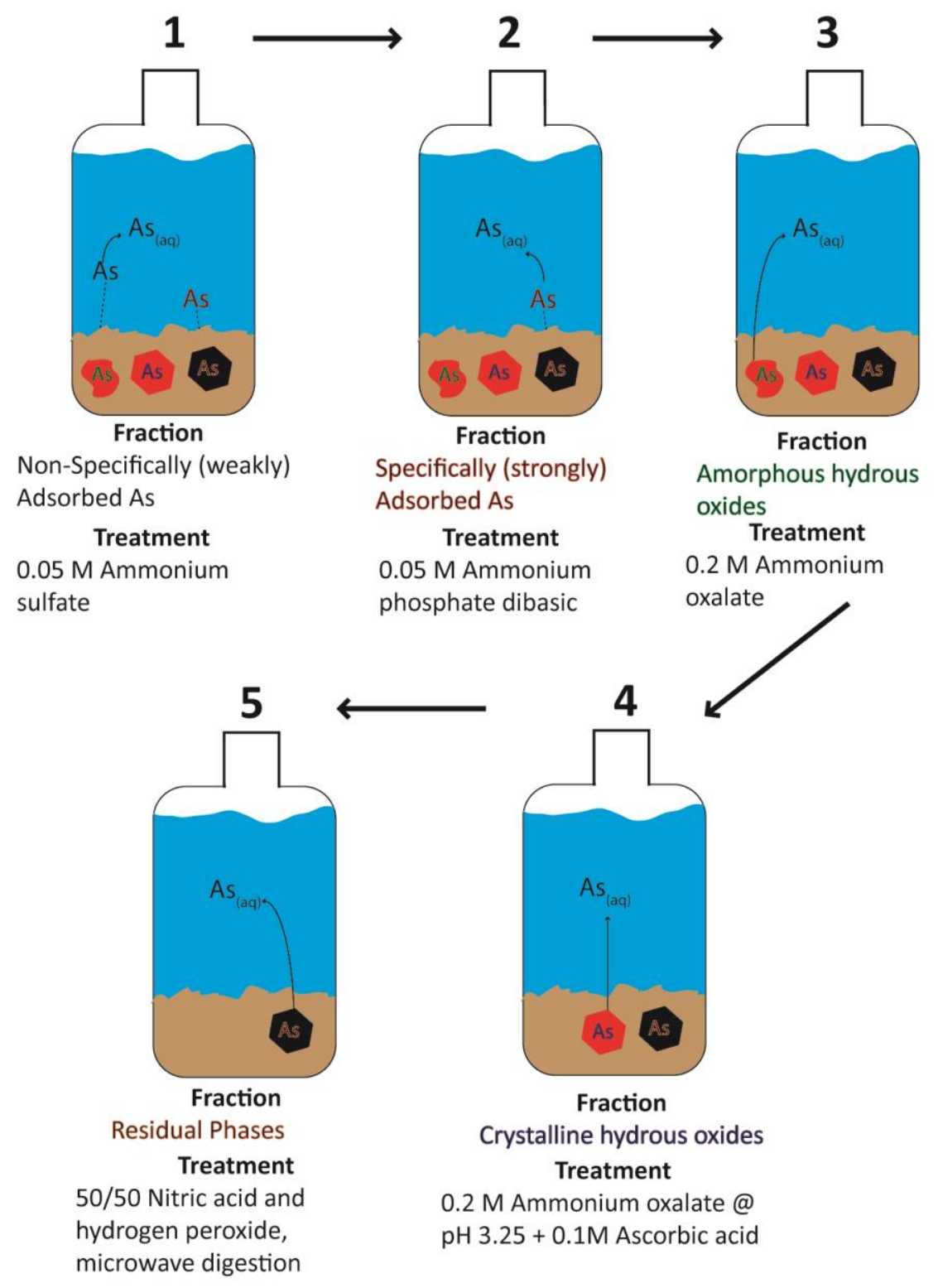

Fig. S1. Sequential fractionation procedure (SEP) for arsenic fractionation 
The anion chemistry of the analyzed samples showed that $\mathrm{HCO}_{3}{ }^{-}, \mathrm{Cl}^{-}, \mathrm{NO}_{3}{ }^{-}$and $\mathrm{SO}_{4}{ }^{2-}$ are the dominant anions in the groundwater and follows the abundance order of $\mathrm{HCO}_{3}{ }^{-}>\mathrm{SO}_{4}{ }^{2-}>\mathrm{NO}_{3}{ }^{-}>\mathrm{Cl}^{-}>\mathrm{F}^{-}$in majority of the groundwater samples. The piper plot [1] (Figure S1) indicates groundwater is predominantly of $\mathrm{Ca}-\mathrm{Mg}-\mathrm{HCO}_{3}$ type. More precisely, groundwater collected from the northeast side of creek were $\mathrm{Ca}-\mathrm{HCO}_{3}$ type whereas samples from southwest were $\mathrm{Mg}-\mathrm{HCO}_{3}$ type (Figure $1 \mathrm{~b}$ ). The $\mathrm{pH}$ of water was in the range of 7.2-8.3, with most of the sample's $\mathrm{pH}$ value close to 7.5.

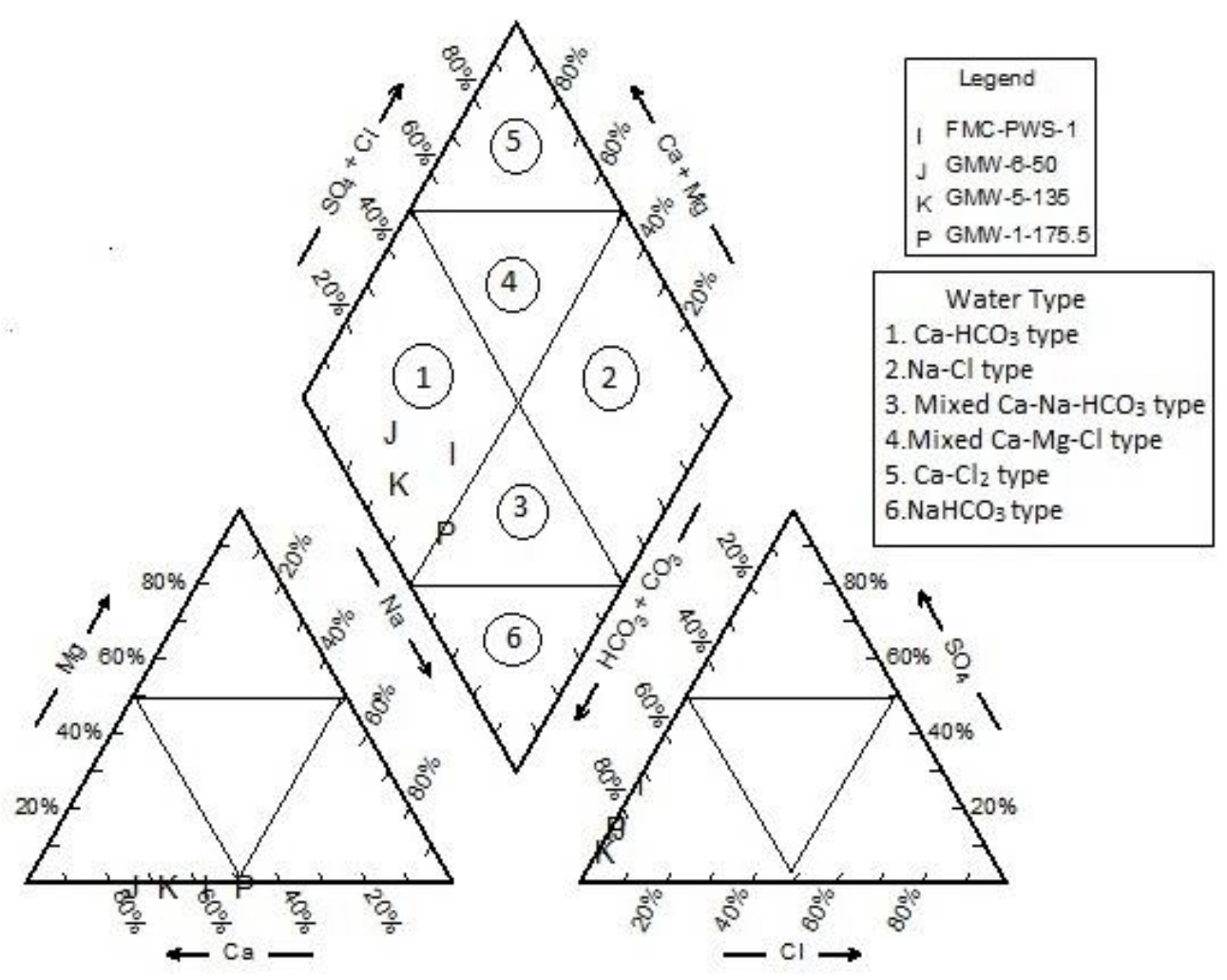

Fig. S2. Trilinear Piper diagram illustrating overall water facies at FMC-PWS-1 (I), GMW-6-50 (J), GMW-5-135(K) and GMW-1-175.5 (P). Most of the samples fall in $\mathrm{Ca}-\mathrm{HCO} 3$ type illustrating good recharge/infiltration. 


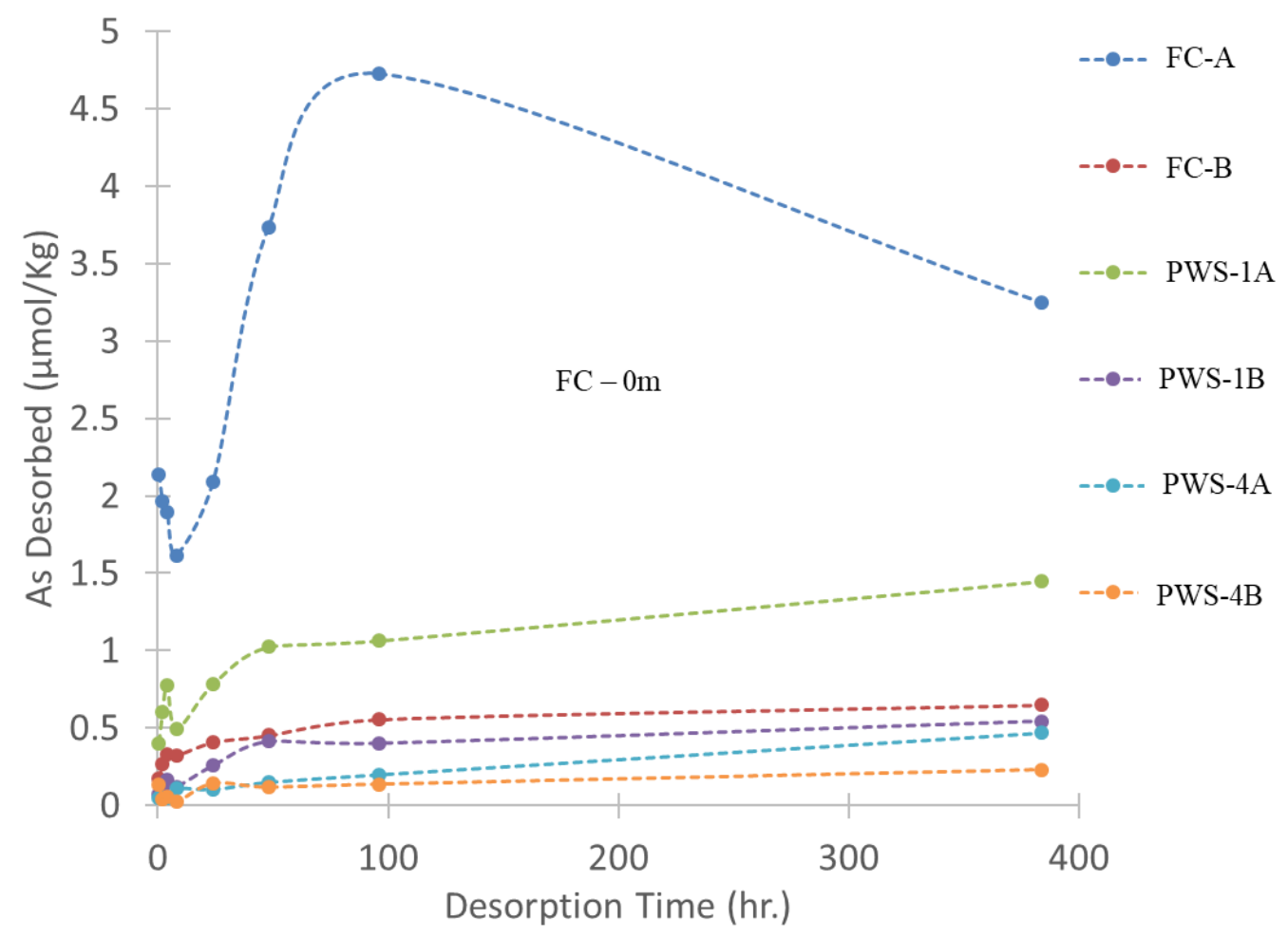

Fig. S3. Shows desorption rate of arsenic for selected sediment samples FC:

Frenchman Creek at FC-A at $0.03 \mathrm{~m}$ and FC-B at $3.3 \mathrm{~m}$ depth, PWS1-A at $5.8 \mathrm{~m}$ and PWS1-B at $34.4 \mathrm{~m}$ depth, and PWS4-A at $18.9 \mathrm{~m}$ and PWS4-B at $34.7 \mathrm{~m}$ depth. 
Table S1. Composition of artificial groundwater (AGW)

\begin{tabular}{|c|c|c|c|}
\hline Parameters & Unit & Values & Chemicals Used \\
\hline $\mathrm{pH}$ & -- & 7.5 & \multirow{9}{*}{$\begin{array}{c}\mathrm{NH}_{4} \mathrm{Cl}, \mathrm{NaHCO}_{3}, \\
\mathrm{NaNO}_{3}, \mathrm{MgCl}_{2} \cdot 6 \mathrm{H}_{2} \mathrm{O}, \\
\mathrm{Ca}(\mathrm{OH})_{2}, \\
\mathrm{MgSO}_{4} \cdot 7 \mathrm{H}_{2} \mathrm{O}\end{array}$} \\
\hline $\mathrm{Ca}$ & $\mathrm{mg} / \mathrm{l}$ & 59.5 & \\
\hline $\mathrm{Mg}$ & $\mathrm{mg} / \mathrm{l}$ & 38.0 & \\
\hline $\mathrm{Na}$ & $\mathrm{mg} / \mathrm{l}$ & 20.5 & \\
\hline $\mathrm{NH}_{4}$ & $\mathrm{mg} / \mathrm{l}$ & 1.7 & \\
\hline $\mathrm{HCO}_{3}$ & $\mathrm{mg} / \mathrm{l}$ & 184.4 & \\
\hline $\mathrm{Cl}$ & $\mathrm{mg} / \mathrm{l}$ & 94.2 & \\
\hline $\mathrm{NO}_{3}$ & $\mathrm{mg} / \mathrm{l}$ & 10.9 & \\
\hline $\mathrm{SO}_{4}$ & $\mathrm{mg} / \mathrm{l}$ & 27.3 & \\
\hline
\end{tabular}


Table S2. Depth-wise oxidation-reduction potential (ORP), $\mathrm{pH}$, and \% $\mathrm{Fe}^{\mathrm{II}}\left(\left(\mathrm{Fe}^{\mathrm{II}}\right.\right.$ /poorly crystalline $\mathrm{Fe}_{\text {Total }} * 100 \%$ ) for sediments from PWS 1, 2, 4 and Frenchman creek.

\begin{tabular}{|c|c|c|c|c|}
\hline $\begin{array}{c}\text { Start } \\
\text { Depth } \\
(\mathrm{m})\end{array}$ & $\begin{array}{l}\text { End Depth } \\
\text { (m) }\end{array}$ & pH & $\begin{array}{l}\text { ORP } \\
(\mathrm{mV})\end{array}$ & $\begin{array}{l}\% \mathrm{Fe}^{\mathrm{II}} \text { from poorly } \\
\text { crystalline FeTotal }\end{array}$ \\
\hline \multicolumn{5}{|c|}{ PWS 1} \\
\hline 4.6 & 5.3 & 6.6 & 126.1 & 35 \\
\hline 7.2 & 7.6 & 6.1 & 193.2 & 2.9 \\
\hline 12.2 & 12.5 & 6.4 & 20.4 & 1.4 \\
\hline 12.5 & 13 & 6.4 & 237.6 & 0 \\
\hline 13 & 13.3 & 6.5 & 119.9 & 38 \\
\hline 13.3 & 13.7 & 6.5 & 139.5 & 0 \\
\hline 13.7 & 14 & 6.8 & 224.9 & 6.1 \\
\hline 14 & 14.5 & 6.6 & 193.3 & 0 \\
\hline 18.3 & 18.6 & 6.7 & -6.9 & 14.9 \\
\hline 18.6 & 19.1 & 6.4 & -19 & 26.9 \\
\hline 19.1 & 19.4 & 6.5 & -137 & 90.6 \\
\hline 19.4 & 19.8 & 6.6 & -99.8 & 90.5 \\
\hline 21.3 & 22.1 & 6.4 & 133.5 & 4.7 \\
\hline 24.4 & 24.7 & 6.8 & -163 & 13.9 \\
\hline 24.7 & 25.1 & 6.8 & -194 & 36.2 \\
\hline 33.5 & 33.8 & NA & NA & 8.5 \\
\hline 33.8 & 34.3 & NA & NA & 7.3 \\
\hline 34.1 & 34.6 & 6.1 & 137.4 & 50 \\
\hline 34.6 & 35.1 & 6.4 & 112.9 & 14.6 \\
\hline $\begin{array}{c}\text { Start } \\
\text { Depth } \\
\text { (m) }\end{array}$ & $\begin{array}{l}\text { End Depth } \\
\text { (m) }\end{array}$ & pH & $\begin{array}{l}\text { ORP } \\
(\mathrm{mV})\end{array}$ & $\begin{array}{c}\% \mathrm{Fe}^{\mathrm{II}} \text { from crystalline } \\
\text { Fet }_{\text {Total }}\end{array}$ \\
\hline \multicolumn{5}{|c|}{ PWS 2} \\
\hline 9.1 & 9.4 & NA & NA & 36 \\
\hline 9.4 & 9.9 & NA & NA & 3 \\
\hline 19.8 & 20.1 & 6.7 & -223 & 26 \\
\hline 20.1 & 20.6 & 6.6 & -225 & 0 \\
\hline 24.4 & 24.7 & 6.3 & 126.8 & 10.4 \\
\hline 24.7 & 25.1 & 5.8 & 106.3 & 20 \\
\hline $\begin{array}{c}\text { Start } \\
\text { Depth } \\
(\mathrm{m})\end{array}$ & $\begin{array}{l}\text { End Depth } \\
\text { (m) }\end{array}$ & pH & $\begin{array}{l}\text { ORP } \\
(\mathrm{mV})\end{array}$ & $\begin{array}{c}\% \mathrm{Fe}^{\mathrm{II}} \text { from crystalline } \\
\text { FeTotal }_{\text {Th }}\end{array}$ \\
\hline \multicolumn{5}{|c|}{ PWS 4} \\
\hline 18.3 & 18.6 & 6.7 & -80.3 & 21 \\
\hline 18.6 & 19.1 & 6.2 & -6.5 & 35 \\
\hline 30.5 & 30.8 & 5.6 & 101.3 & 21 \\
\hline 30.8 & 31.2 & 6.2 & 188.1 & 30 \\
\hline
\end{tabular}




\begin{tabular}{|c|c|c|c|c|}
\hline 33.2 & 33.5 & 6 & -100.8 & 23 \\
\hline 33.5 & 34 & 5.8 & -121.7 & 14 \\
\hline 34 & 34.3 & 6 & -101.1 & 11 \\
\hline 34.3 & 34.7 & 6 & -61 & 17 \\
\hline 41.9 & 42.2 & 5.4 & 59 & 0 \\
\hline 42.2 & 42.7 & 5.7 & 25 & 10 \\
\hline 46.5 & 46.8 & 6.2 & -80 & 22 \\
\hline 46.8 & 47.2 & 6.5 & -67.4 & 46 \\
\hline $\begin{array}{c}\text { Start } \\
\text { Depth } \\
(\mathbf{m})\end{array}$ & $\begin{array}{l}\text { End Depth } \\
\text { (m) }\end{array}$ & $\mathbf{p H}$ & $\begin{array}{l}\text { ORP } \\
(\mathbf{m V})\end{array}$ & $\begin{array}{c}\% \mathrm{Fe}^{\mathrm{II}} \text { from crystalline } \\
\text { Fe }\end{array}$ \\
\hline \multicolumn{5}{|c|}{ Frenchman Creek } \\
\hline \multicolumn{2}{|c|}{ Creek bed } & 6.4 & -192.9 & 88 \\
\hline 0 & 0.3 & 6.4 & 56.6 & 81 \\
\hline 0.3 & 0.8 & 6.3 & -36.5 & 79 \\
\hline 0.8 & 1.5 & 6.2 & 71.4 & 15 \\
\hline 1.5 & 1.8 & 6.8 & -56.9 & 78 \\
\hline 1.8 & 2.3 & 6.7 & -89.8 & 88 \\
\hline 2.3 & 2.6 & 6.6 & 22.2 & 10 \\
\hline 2.6 & 3 & 6.8 & 7 & 0 \\
\hline 3 & 3.4 & 6 & 120 & 16 \\
\hline 3.4 & 3.8 & 6.5 & 133.9 & 37 \\
\hline 3.8 & 4.1 & 6.9 & -238.9 & 12 \\
\hline 4.1 & 4.6 & 7 & -236.3 & 32 \\
\hline 4.6 & 5.3 & 6 & 176.8 & 29 \\
\hline 5.3 & 5.6 & 5.9 & 207.7 & 2 \\
\hline 5.6 & 6.1 & 5.8 & 195.4 & 0 \\
\hline 6.1 & 6.4 & 6.7 & -169 & 4 \\
\hline 6.4 & 6.9 & 6.4 & -51.8 & 32 \\
\hline 7.6 & 8.4 & 6.7 & -185.4 & 44 \\
\hline 8.4 & 8.7 & 6.6 & -332 & 35 \\
\hline 8.7 & 9.1 & 6.8 & -291 & 8 \\
\hline
\end{tabular}

$* \mathrm{NA}=$ not analyzed. 
Table S3. Shows dissolved organic carbon (DOC) concentration in water samples.

\begin{tabular}{lc}
\hline & Groundwater \\
\hline Sample ID & $\begin{array}{c}\mathrm{DOC} \\
\mu \mathrm{g}-\mathrm{C} \mathrm{g}^{-1}\end{array}$ \\
\hline GMW-6-50 & 0.63 \\
GMW-5-135 & 0.99 \\
PWS-1 & 0.99 \\
GMW 4-77 & 0.76 \\
GMW 3-105.5 & 0.69 \\
GMW 2-147 & 1.32 \\
GMW 1-175.5 & 0.52 \\
WHS-FP1 & 1.60 \\
WHS-FP2 & 2.06 \\
WHS-FP3 & 3.66 \\
RDW-1 & 0.75 \\
RDW-2 & 0.69 \\
PWS-4 & 0.52 \\
\hline & \\
\hline Sample ID & $\mathrm{DOC}$ \\
& Surface water \\
\hline FMC-HW & 10.85 \\
FMC-HW-5m & 5.62 \\
ER & 5.39 \\
ERD & 3.21 \\
FMC-PSW-1 & 3.02 \\
\hline
\end{tabular}

\section{References}

[1] A.M. Piper, A graphic procedure in the geochemical interpretation of water???analyses, Eos, Trans. Am. Geophys. Union. 25 (1944) 914-928. https://doi.org/10.1029/TR025i006p00914. 